\title{
Dimethylsulfoniopropionate and dimethylsulfoxide in Posidonia oceanica
}

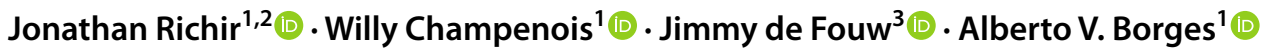

Received: 14 December 2020 / Accepted: 24 August 2021

(c) The Author(s), under exclusive licence to Springer-Verlag GmbH Germany, part of Springer Nature 2021

\begin{abstract}
The present work aims at determining the natural variability of dimethylsulfoniopropionate (DMSP) and dimethylsulfoxide (DMSO) contents in the seagrass Posidonia oceanica, which is the largest producer of these molecules reported to date among coastal autotrophs. Seagrass leaf samples were collected during a period of 3.5 years in the pristine Revellata Bay (Calvi, northwestern Corsica, France). The DMSP content ranged from 25 to $265 \mu$ mol.g $\mathrm{f}_{\mathrm{fw}}{ }^{-1}$; DMSO from 1.0 to $13.9 \mu_{\mathrm{mol} . \mathrm{g}_{\mathrm{fw}}}{ }^{-1}$. The dynamics of the two molecules were closely linked, the DMSO content being equivalent to 3.5\% of the DMSP content, all leaf samples considered $(n=423$ samples and $414 \mathrm{DMSP}(\mathrm{O})$ data pairs). The annual growth cycle of the seagrass diluted the initial stocks of the two molecules. Temperature indirectly affected molecule content dynamics through their direct effect on the seagrass productivity and biomass. Inter-annual variations in $\operatorname{DMSP}(\mathrm{O})$ content in relation to shallow water temperature might further indicate that $\mathrm{DMSP}(\mathrm{O})$ could have been involved in the physiological response of $P$. oceanica to heat stress. Finally, middle-aged leaf tissues with an organosulfur molecule content similar to the average value calculated for the seagrass leaf bundle appeared to be the best choice of sample material to study DMSP and DMSO in that species. More research is needed to elucidate the biosynthetic pathways of these molecules in seagrasses, the evolutionary reasons for such a high production in $P$. oceanica and the physiological functions they play.
\end{abstract}

Keywords Dimethylsulfoniopropionate $\cdot$ Dimethylsulfoxide $\cdot$ Sulfur metabolism $\cdot$ Seagrass $\cdot$ Posidonia oceanica

\section{Introduction}

Haas (1935) showed that the red macroalgae Polysiphonia fastigiata and P. nigrescens when exposed to air emitted dimethyl sulphide (DMS). It was unlikely that DMS was stored as such in the macroalgae, given the small size of the

Responsible Editor: by K. Bischof.

Reviewed by undisclosed experts.

Jonathan Richir

jonathan.richir@uliege.be

$\triangle$ Alberto V. Borges

alberto.borges@uliege.be

1 Chemical Oceanography Unit, FOCUS, University of Liège, Liège, Belgium

2 Laboratory of Oceanology, FOCUS, University of Liège, Liège, Belgium

3 Department of Aquatic Ecology and Environmental Biology, Institute for Water and Wetland Research, Radboud University, Nijmegen, The Netherlands molecule and its high diffusivity. This suggested the occurrence of a precursor sulphonium compound, identified as DMSP by Challenger and Simpson (1948). The first report on the second biogenic precursor of DMS in marine algae, dimethylsulfoxide (DMSO) is more recent. Given the large, often dominant pool of DMSO in aquatic environments, it was hard to envisage its maintenance solely via a DMS precursor (Lee and de Mora 1999). de Mora et al. (1996) speculated a direct biosynthetic pathway on the basis of evidence gathered in Antarctic melt-water ponds that contained relatively high levels of dissolved DMSO but low concentrations of DMS and very little dissolved DMSP. In the coastal waters of North Island, New Zealand, Lee and de Mora (1996) speculated that algal photosynthetic processes may have played a role in the rapid daytime production of dissolved DMSO that could not have only resulted from photo- and bacterial oxidation of DMS. Simó et al. (1998) confirmed the biogenic production of DMSO by marine microalgae in laboratory cultures of Amphidinium carterae and Emiliania huxleyi. 
Since these initial results reporting DMSP and DMSO associated with macroalgae and phytoplankton (Challenger and Simpson, 1948; Simó et al., 1998), a number of studies have addressed first their occurrence and production, then their biosynthesis in marine primary producers (Lee and de Mora 1999; Lee et al. 1999; Stefels 2000; Hatton et al. 2004; Stefels et al. 2007). DMS, DMSP and DMSO are tightly interrelated compounds that constitute an integral part of the marine sulfur cycle and play an important role in the global sulfur budget (Stefels et al. 2007; Asher et al. 2017). The proposed cooling effect on climate through increased albedo of DMS-derived cloud condensation nuclei (Lovelock and Maggs 1972; Charlson et al. 1987) has stimulated considerable research into this gas and its precursors during the last three decades. The recent discovery of a new metabolite, dimethylsulfoxonium propionate (DMSOP) synthesized by several DMSP-producing microalgae and marine bacteria, has extended the paradigm of the marine sulfur cycle (Thume et al. 2018).

DMSP and DMSO are ubiquitous in the upper ocean (Lee et al. 1999; Simó and Vila-Costa 2006). Their biogenic production is, however, taxon-dependent and large producers are confined to a few classes of micro- and macroalgae (Stefels 2000; Simó and Vila-Costa 2006; Hatton and Wilson 2007). Unlike algae, for which an important scientific literature is available, observations of DMSP (and DMSO) in higher plants are rare (Stefels 2000). Vegetated sediments of salt marshes are major sources of DMS emission to the atmosphere (Steudler and Peterson 1984). It was obvious to investigate their biogenic precursors in the dominant grasses of these systems, i.e. plants of the genus Spartina. DMSP was first reported in Spartina anglica (Larher et al. 1977), later in S. alterniflora (Dacey et al. 1987) and in S. foliosa (Otte and Morris 1994). The first report of DMSO in salt marsh grasses is more recent. Its discovery in S. alterniflora by Husband and Kiene (2007) relied on the idea that if DMSO was present in some DMSP-producing phytoplankton, this compound might also be found in DMSP producing higher plants. These authors reported DMSO content in ratio to DMSP of $1.6-4.0 \%$, values much lower than for phytoplankton (8-50\%; Simó and Vila-Costa 2006).

Reports of DMSP and DMSO in seagrasses are even more rare than in cordgrasses. White (1982) when developing a method for the analysis of dimethyl sulfonium compounds in marine macrophytes, measured DMSP in Zostera sp. [most probably Z. marina, the dominant native Zostera species on the Pacific coast of North America (Green and Short 2003) and referred as such by Dacey et al. (1987)], although its production was likely affected by algal epiphytes (Bianchi 2007). In the mid-90 s, Dacey et al. (1994) measured DMSP in the epiphytized leaves of three seagrasses: Halodule wrightii, Syringodium filiforme and Thalassia testudinum; they attributed DMSP mostly to leaf epiphytes, since DMSP content in $T$. testudinum non-epiphytized leaves was 3-8 times lower. Very low DMSP contents were also reported in non-epiphytized leaves of Z. noltei (Jonkers et al. 2000), in roots of that species (Jonkers et al. 2000) and in rhizomes of T. testudinum (Dacey et al. 1994).

In the oligotrophic coastal ecosystem of Niel Bay (NW Mediterranean, France), algal biomass and particulate DMSP were low; because phytoplankton alone could not fully explain the high dissolved DMSP levels measured there, Jean et al. (2006, 2009) assumed benthic macrophytes including Posidonia oceanica contributed to the dissolved DMSP pool. This assumption was recently confirmed by Borges and Champenois (2015), who resurrected the interest in the production of DMSP by seagrasses by investigating its content in P. oceanica; they also showed the occurrence of DMSO in this plant (Borges and Champenois 2017). DMS was further reported to be the main volatile organic compound (59.3\%) in P. oceanica (Jerković et al. 2018), de facto explained by the high values of DMSP and DMSO measured in its leaves (Borges and Champenois 2017; Richir et al. 2020). P. oceanica is a top producer of DMSP and DMSO among marine and intertidal autotrophs, with foliar contents reaching up to $265 \mu \mathrm{mol}_{\mathrm{g}} \mathrm{g}^{-1}$ for DMSP and $13 \mu \mathrm{mol}^{\mathrm{g}} \mathrm{g}_{\mathrm{fw}}{ }^{-1}$ for DMSO (Richir et al., 2020). The production dynamics of the two molecules in P. oceanica are closely linked and depend more on the plant's annual growth cycle than on environmental variables (light and temperature; Richir et al. 2020). DMSP and DMSO, more concentrated in young tissues, could play antioxidant and grazer deterrent functions (Richir et al. 2020). Their ratio, considering DMSO is the product of the oxidation of DMSP, could be a generic indicator of oxidative stress in the plant (Richir et al. 2020), as initially postulated and verified for S. alterniflora (Husband and Kiene 2007; Husband et al. 2012; McFarlin and Alber 2013).

The present work aims at determining the natural variability of the DMSP and DMSO contents in P. oceanica leaves (i) at seasonal and interannual time scales, (ii) with depth, (iii) in relation to the ageing of leaf tissues and (iv), in the context of ocean warming, with water temperature. This complete and detailed, depth gradient $(10-30 \mathrm{~m})$ study of almost 3.5 years (April 2015-August 2018) on the ecophysiology of DMSP(O) in $P$. oceanica leaves was carried out in a non-disturbed meadow in Corsica, France, in the framework of the STARECAPMED program (Richir et al. 2015). In addition to P. oceanica, some preliminary, indicative data on $\mathrm{DMSP}(\mathrm{O})$ contents in $Z$. marina and Cymodocea nodosa leaves are also given.

\section{Materials and methods}

\section{Study design}

To study the natural variability of DMSP and DMSO contents in $P$. oceanica leaves over time, we compiled and 
analysed a large data set of novel unpublished data $(n=293$ samples and $285 \mathrm{DMSP}(\mathrm{O})$ data pairs) and previously published data ( $n=130$ samples and $129 \operatorname{DMSP}(\mathrm{O})$ data pairs) by Richir et al. (2020). The previous data set covered, on a weekly to fortnightly basis, the period from mid-April to mid-July 2016 (Richir et al. 2020) to which we added additional unpublished data collected in May, August and November 2016, February, August and November 2017, and February, May and August 2018 (see Sect. Seagrass sample collection for details). For these additional May 2016 to August 2018 data, sampling was systematically carried out along a 10-30 m depth gradient (unlike the study of Richir et al. (2020) that mainly focused on the depth of $10 \mathrm{~m}$ ). The compiled data set $(n=423$ samples and 414 DMSP(O) data pairs) allowed to explore the seasonal and interannual variations of the seagrass leaf $\operatorname{DMSP}(\mathrm{O})$ content in relation to those of temperature, that were marked during time period given strong heatwave in 2018 (Liu et al. 2020); it further allowed to test the hypothesis of the involvement of $\operatorname{DMSP}(\mathrm{O})$ in the physiological response of $P$. oceanica to heat stress. Also, Richir et al. (2020) only reported variations of the DMSP $(\mathrm{O})$ content in the first 20 basal $\mathrm{cm}$ of $P$. oceanica third rank leaf. Here, we explored the variability of the $\operatorname{DMSP}(\mathrm{O})$ content in leaves of different rank, i.e. age classes, from their base towards their tip $(10 \mathrm{~cm}$ long leaf section; Suppl. Mat. Figure 1). P. oceanica shoot structure is characterized by the distichous and alternating arrangement of its ribbon-like leaves, with the youngest ones at the center of the shoot, and the oldest ones on the outside (Buia et al. 2004; Augier 2007); foliar tissues are, therefore, older towards the outside of the leaf bundle and the tip of the leaf. In addition, the analysis of the leaf class and leaf section variability provided important information for the design of the best leaf tissue sampling protocol for assessing organosulfur dynamics in P. oceanica.

\section{Study site}

The study was conducted in a dense and healthy P. oceanica meadow in the northwestern part of the Revellata Bay in the Gulf of Calvi (Corsica, France; Norie 1831), close to the STARESO research station $\left(42.580^{\circ} \mathrm{N}, 8.725^{\circ} \mathrm{E}\right)$. The Gulf of Calvi has an area of about $22 \mathrm{~km}^{2}$, opens to the Ligurian Sea on the northeast with a border of about $6 \mathrm{~km}$ and connects to the deep sea by a canyon. The Gulf of Calvi is a 'reference site' in a good state of environmental conservation (Gobert et al. 2009; Lopez y Royo et al. 2010, 2011). The sea floor is dominated by a dense and healthy $P$. oceanica meadow down to about $38 \mathrm{~m}$ depth (Bay 1984; Champenois and Borges 2012; Richir et al. 2015). The study site of the present work is identical to that of Borges and Champenois (Borges and Champenois 2015, 2017) and Richir et al. (2020).

\section{Water temperature recording}

Water temperature was recorded continuously with probes and loggers deployed in the P. oceanica meadow facing the STARESO. Temperature data were accessed from the RACE database (Binard 2017). Temperature was recorded at 9.5 (considered 10) $\mathrm{m}$ depth with the incorporated temperature sensor of an Aanderaa oxygen optode (3835) mounted on Alec Instrument data-loggers (60 min interval; Xylem Inc.; Champenois and Borges 2012), and at 20 and 29 (considered 30) $\mathrm{m}$ depth with Hobo loggers (10 min interval; HOBO Pendant ${ }^{\circledR}$ Temperature/Light Data Logger, Onset Computer Corporation; Richir et al. 2020). The temperature sensors of the Aanderaa oxygen optode and the Hobo loggers were factory-calibrated.

\section{Seagrass sample collection}

$P$. oceanica sampling was performed weekly to seasonally by scuba diving between April 2015 and August 2018 . Three successive sampling designs were performed over that period: in years 2015-2016 (first), 2016-2017 (second) and 2017-2018 (third), as described below. P. oceanica sampling was performed in triplicate, on orthotropic shoots [i.e. vertical growth, as opposite to plagiotropic (horizontal) growth; Boudouresque et al. 2012] randomly selected on surfaces of a few $\mathrm{m}^{2}$. Sampling was performed by cutting the leaves just above the meristem area with a scissor to ensure their post-regrowth (Suppl. Mat. Figure 1A; de los Santos et al. 2016; Gobert et al. 2020).

Between April 2015 and July 2016, the first seagrass sampling design was performed at $10 \mathrm{~m}$ depth, at a weekly to fortnightly frequency; in July 2015 , seagrasses were sampled along a depth gradient at 3, 10, 15, 20, 25, 29 (considered $30)$ and $36 \mathrm{~m}$ depth. Only the third leaf from the inside of the leaf bundle [i.e. rank 3 ; juvenile leaves $(<5 \mathrm{~cm}$ long; Giraud 1979) were excluded] was sampled. The first 20 basal $\mathrm{cm}$ of sampled leaves were dissected for analysis (see Richir et al. 2020).

In May, August and November 2016 and in February 2017, the second seagrass sampling design was performed along the depth gradient at 10,15,20,25 and $30 \mathrm{~m}$ depth. Only the third external leaf from the outside of the leaf bundle (usually rank 4) was sampled. The first 10 basal $\mathrm{cm}$ of sampled leaves were dissected for analysis. P. oceanica shoots have in average six leaves (Gobert et al. 2003; Richir et al. 2020); whether taken from outside (second sampling design) or inside (first sampling design) the bundle, the third leaf is, therefore, similar (rank 3 or 4; Suppl. Mat. Figure 1A).

In August and November 2017 and in February, May and August 2018, the third seagrass sampling design was performed along the depth gradient at 10,15, 20, 25 and 
$30 \mathrm{~m}$ depth. Entire $P$. oceanica leaf bundles were sampled. Leaf bundles were clipped in situ with plastic tongs prior cutting to keep the insertion order of the leaves. The leaves were sorted and pooled into three classes: the two most external leaves on each side (called 'external'), the following two leaves on each side (called 'intermediary'), all of the following leaves (called 'internal'). Pooled leaf classes were then cut into four sections of $10 \mathrm{~cm}(0-10$, 10-20, 20-30 and 30-40 cm) for analysis (Suppl. Mat. Figure 1B). The leaf grows from the base (acropetal growth; Boudouresque et al. 2012), so the younger section of the leaf corresponded to the first section $(0-10 \mathrm{~cm})$ according to our convention. Because most leaf tips of the August 2017 samples were necrotic (most of leaves, old and senescent, are ready to decay at the end of summer), only the 40 first $\mathrm{cm}$ of $P$. oceanica living leaf tissues were considered.

Quickly after the end of the dive, seagrass leaf samples were dissected in STARESO facility, then prepared and stored according to the protocol of Borges and Champenois (2017). Briefly, leaf samples were cleaned of epiphytes (when present) with a razor blade (Dauby and Poulicek 1995) during dissection, and lower little-pigmented sections of sampled leaves systematically discarded. Dissected leaf tissues were stored in $20 \mathrm{ml}$ borosilicate vials sealed with polytetrafluoroethylene coated silicone septa stopper or in plastic bags and frozen at $-20{ }^{\circ} \mathrm{C}$ until DMSP and DMSO analysis. Samples were brought back frozen to the University of Liège (Belgium) to avoid DMSP loss during transport.

In addition to $P$. oceanica sampling and for comparison purpose between temperate seagrass species, $C$. nodosa (subtidal species) and Z. marina (predominantly subtidal species) shoots were collected in August of years 2018 and 2019; in Alfax Bay, Spain, for C. nodosa, and in three sites in Brittany (Kernisi, Dinard, Port Laso), France, and in Kristineberg, Sweden for Z. marina (Table 1). Sampling depth was $30-150 \mathrm{~cm}$, except for Dinard Z. marina sampling (emerged at low tide). Seagrass shoots were rinsed with water to get rid of the sediment, then brought back frozen to Radboud University (The Netherlands). In the laboratory, unfrozen seagrass shoots were dissected, and leaf bundles cleaned of epiphytes reconditioned frozen and sent to the University of Liège (Belgium) for DMSP and DMSO analysis. Complete seagrass leaf bundles were pooled into one to three sample replicates per site, of about $500 \mathrm{mg}$ each (preliminary test analyses showed low organosulfur compound contents). Samples were processed for DMSP and DMSO content in a similar fashion as for P. oceanica leaves (see section below).

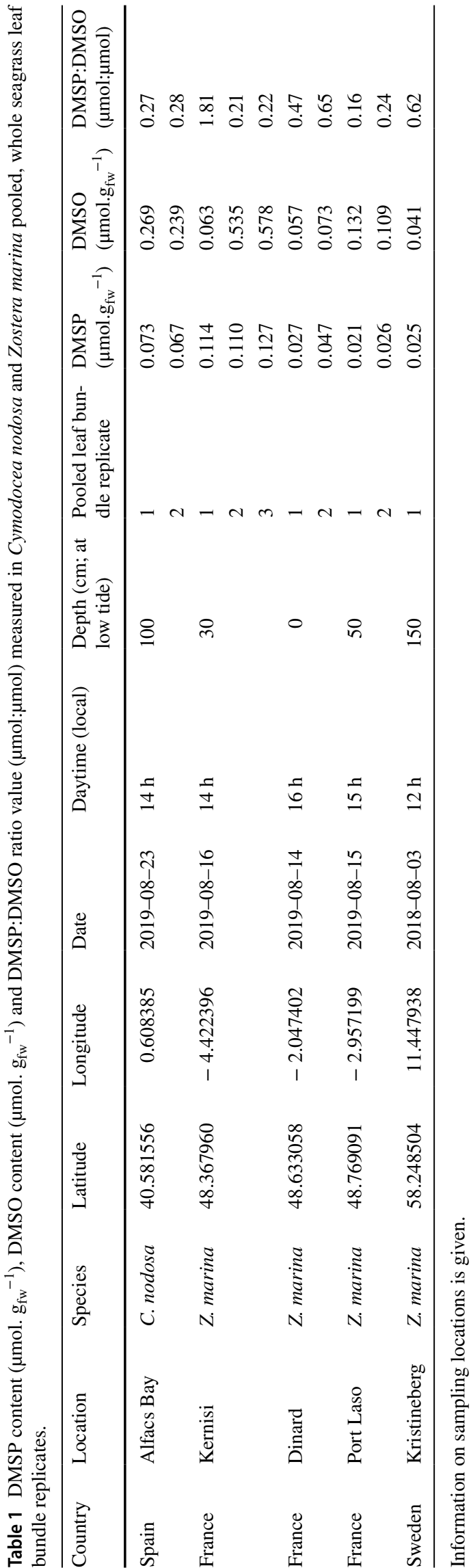




\section{DMSP and DMSO analysis}

P. oceanica dissected leaves sampled for DMSP and DMSO analysis were unfrozen, gently dried of water droplets on absorptive paper and cut in $3 \mathrm{~mm}^{2}$ square fragments. In average, $31 \mathrm{mg}$ of fresh leaf tissue $(7-50 \mathrm{mg}$, according to tissue availability and expected organosulfur compound contents) were transferred to pre-weighted $20 \mathrm{ml}$ glass vials for analysis (three analytical replicates by leaf sample except for years 2016-2017s sampling design and for C. nodosa and Z. marina, no analytical replicate; Borges and Champenois 2017). DMSP and DMSO contents were measured after conversion into DMS using the headspace technique with a gas chromatograph (GC) with a flame photometric detector (FPD) (Agilent 7890A, Thermo Fisher Scientific Inc.). The temperature of the FPD was kept at $250{ }^{\circ} \mathrm{C}$ with $\mathrm{H}_{2}$ and synthetic air flows (respectively, 50 and $60 \mathrm{ml} \cdot \mathrm{min}^{-1}$; Air Liquide Belgium). The column was a capillary column (CP-Sil 5CB, $30 \mathrm{~m}$ long, $0.32 \mathrm{~mm}$ internal diameter, $0.5 \mathrm{~mm}$ film thickness, CSChromatographie Service $\mathrm{GmbH}$ ), the carrier gas ultrapure He ( 2 ml. $\mathrm{min}^{-1}$; alphagas-2 grade, Air Liquide Belgium). The temperature of the oven and injection port was kept at $60{ }^{\circ} \mathrm{C}$. The headspace was sampled with syringes of $10-500 \mu \mathrm{L}$ and injected through a split-splitless injection port to the head of the column. The methodology for seagrass leaf sample preparation and $\operatorname{DMSP}(\mathrm{O})$ analysis is fully detailed in Champenois and Borges (2019). In brief, the method consists of first digesting $P$. oceanica leaf fragments in $2.5 \mathrm{ml}$ of $\mathrm{NaOH}$ (12 M; solution prepared from granular $\mathrm{NaOH}$, VWR International, LLC) in the $20 \mathrm{ml}$ closed vials. In the presence of $\mathrm{NaOH}$, DMSP cleaves quantitatively into DMS and acrylate (Stefels 2009). The DMS in the vial headspace is measured by GC-FPD. The $\mathrm{NaOH}$ digestate is then bubbled with ambient air to evacuate the DMS and acidified with $2.5 \mathrm{ml}$ of pure $\mathrm{HCl}$ (12 M; HCl 37\% Normapur, VWR International, LLC). The DMSO present in the digestate is reduced to DMS by adding $1 \mathrm{ml}$ of $\mathrm{TiCl}_{3}\left(\mathrm{TiCl}_{3} 30 \% \mathrm{~m} / \mathrm{v}\right.$, Merck KGaA; Stefels 2009). The DMS in the vial headspace is again measured by GC-FPD. Median (min-max) headspace volumes sampled for direct injection were $10 \mu \mathrm{l}(8-500 \mu \mathrm{l})$ for DMSP, and $100 \mu \mathrm{l}(25-500 \mu \mathrm{l})$ for DMSO, respectively, all samples considered. The GC-FPD peaks of DMS were converted into DMSP and DMSO concentrations from a series of standards of known concentrations treated in the same way and at the same time as the samples. Digestate DMSP and DMSO concentrations were converted to leaf contents ( $\mu$ mol per $\mathrm{g}$ of leaf fresh weight, $\mu$ mol. $\mathrm{g}_{\mathrm{fw}}{ }^{-1}$ ). The ratio of DMSP on DMSO was computed from the measured DMSP and DMSO contents. The DMSP $(\mathrm{O})$ set of individual data (averages of analytical replicates) and temperature data are hosted in the Mendeley Data repository (https://doi.org/10.17632/y65hzhbfsk.1).

\section{Data processing and statistical analysis}

The spatiotemporal and compartmentalisation analysis of DMSP and DMSO consisted of linear mixed effects models (LMMs). LMMs extend traditional linear models to include a combination of fixed and random effects as predictor variables (Harrison et al. 2018). Fixed effects represent variables with intercepts, means or slopes to be estimated; random effects infer the variance associated with group membership (Silk et al. 2020). The model we used included depth, period and leaf class as fixed effects, and leaf section as random effect. LMM $p$ values were computed by using Satterhwaite approximation for denominator degrees of freedom (Satterthwaite 1946). Analysis of variance (one- and two-way ANOVAs) on mean DMSP, DMSO and DMSP:DMSO ratio data for the basal section of $P$. oceanica rank 3-4 leaves were used to study the effect of year (2015-2016-20172018) and season (autumn, winter, spring, summer), followed by Tukey's post hoc comparison test (Zar 2010). Linear modelling (LMMs and ANOVAs) was performed on log-transformed data.

DMSP and DMSO contents of the maximum twelve leaf class-section combinations of the compartmentalisation study were averaged to calculate $P$. oceanica leaf bundle values. They were also averaged to calculate six new 0-20 and $20-40 \mathrm{~cm}$ leaf class-section combinations. The leafclass sections of 10 or $20 \mathrm{~cm}$ long were proportionally compared to the seagrass DMSP and DMSO content averages to determine which one best represents the whole $0-40 \mathrm{~cm}$ leaf bundle.

The linear relationship between DMSP and DMSO contents in $P$. oceanica leaf tissues of the three sampling designs ( $n=414$ data pairs) was analysed using bootstrapped median regression. Quantile (including median) regression presents several advantages for ecological data: it is robust to outliers; avoids parametric distribution assumptions; estimates rates of change in all parts of the response variable distribution and is invariant to monotonic transformations (Koenker and Bassett 1978; Cade and Noon 2003). The $\mathrm{R}_{1}$ goodness of fit of the model was measured according to Koenker and Machado (1999). The 0.95 prediction interval was created using quantiles 0.025 and 0.975 .

The relationships among response variables DMSP, DMSO or DMSP:DMSO ratio and the potential explanatory variable temperature were analysed using median regression with restricted cubic spline function and best linear fit lines. Cubic spline is essentially a piecewise cubic polynomial. Cubic polynomials have good ability to fit sharply curving shapes. Cubic spline is made to be smooth at the join points, called knots. A restricted cubic 
spline has the additional property that the curve is linear before the first knot and after the last knot. The number of knots used in the spline is determined by the user, but in practice, five or fewer knots are sufficient (Harrell 2015; Gauthier et al. 2019). In the present study, we used one knot as free parameter. Differences in temperature summer maxima were measured for years 2015 to 2018, with daily average values sometimes close to $28{ }^{\circ} \mathrm{C}$. Relationships were therefore analysed for July and August data. $P$. oceanica tissue considered for the analysis was the basal section analysed for each sampling design $(0-20 \mathrm{~cm}$ for years 2015-2016, 0-10 cm for years 2016-2017 and years 2017-2018). In addition, July and August daily mean temperatures used in the models were values greater than or equal to their respective 75 th percentiles.

Data analysis and statistics were performed in RStudio version 1.1.383 (RStudio Team 2019), using R's base function (R Core Team 2020) and functions of packages 'dplyr' (Wickham et al. 2019), 'tidyr' (Wickham and Henry 2019), 'ImerTest' (Kuznetsova et al. 2017), 'car' (Fox and Weisberg 2019), 'agricolae' (de Mendiburu 2020), 'ggplot2' (Wickham 2016), 'quantreg' (Koenker 2019) and 'rms' (Harrell 2019). Linear model assumptions (including residual distribution, variance homoscedasticity and overdispersion) and model fits were checked with diagnostic plots and tests. Statistical results are given according to Wasserstein (2019).

\section{Results}

According to the LMM analysis, DMSP and DMSO in $P$. oceanica varied over time (DMSP: $F(4202.20)=58.32$, $p<2.2 \times 10^{-16} ; \quad$ DMSO $: \quad F(4201.53)=51.29$, $\left.p<2.2 \times 10^{-16}\right)$ and among leaf classes, i.e. leaf age (DMSP: $F(2201.49)=69.03, p<2.2 \times 10^{-16}$; DMSO: $\left.F(2200.69)=69.47, p<2.2 \times 10^{-16}\right)$. Depth also had an effect on organosulfur compound contents (DMSP: $F(4201.26)=4.85, p=0.0010$; DMSO: $F(4200.86)=3.02$, $p=0.0190)$, as did the interaction between period and depth (DMSP: $F(16,200.89)=2.48, p=0.0019$; DMSO: $\left.F(16,200.52)=4.20, p=5.3 \times 10^{-7}\right)$. The DMSP leaf content (Fig. 1, Suppl. Mat. Figure 2A) ranged from $25 \mu \mathrm{mol}^{\mathrm{g}} \mathrm{fw}^{-1}$ (external leaf, section 10-20 cm, August 2017, $10 \mathrm{~m} \mathrm{depth}$ ) to $167 \mu$ mol. $\mathrm{g}_{\mathrm{fw}}{ }^{-1}$ (external leaf, section 20-30 cm, February 2018, $15 \mathrm{~m}$ depth), for an average value of $78 \pm 26 \mu$ mol. $\mathrm{g}_{\mathrm{fw}}{ }^{-1}$ [mean \pm standard deviation (SD), $n=230$ ]. The DMSO leaf content (Fig. 1, Suppl. Mat. Figure $2 \mathrm{~B}$ ) ranged from $0.9 \mu \mathrm{mol}_{\mathrm{fw}}{ }^{-1}$ (external leaf, section 0-10 cm, August 2018, $15 \mathrm{~m}$ depth) to $7.1 \mu \mathrm{mol} . \mathrm{g}_{\mathrm{fw}}{ }^{-1}$ (internal leaf, section 0-10 cm, August 2017, $30 \mathrm{~m}$ depth), for an average value of $3.3 \pm 1.4 \mu \mathrm{mol}_{\mathrm{g}} \mathrm{g}_{\mathrm{fw}}{ }^{-1}$ (mean $\pm \mathrm{SD}$, $n=230$ ). Overall, the DMSP leaf content was higher in February compared to other periods and increased from external to internal leaves; it was lower at intermediate 15-20 m depths. This pattern for DMSP was similar for DMSO. The DMSP:DMSO ratio value (Fig. 1, Suppl. Mat. Figure 2C) ranged from $13 \mu \mathrm{mol}: \mu \mathrm{mol}$ to $52 \mu \mathrm{mol}: \mu \mathrm{mol}$, for an average value of $25 \pm 7 \mu$ mol: $\mu \mathrm{mol}$ (mean $\pm \mathrm{SD}, n=230$ ). Out of the 230 DMSP:DMSO ratio values, 59 were lower than $20 \mu \mathrm{mol}: \mu \mathrm{mol}$, including 22 lower than $18 \mu \mathrm{mol}: \mu \mathrm{mol}$. Averaged by factor (period, depth, leaf class), all ratio values except August 2018 were between 20 and $27 \mu$ mol: $\mu$ mol.

The number of $P$. oceanica leaf samples analysed for DMSP and DMSO according to period (5), depth (5), leaf class (3) and leaf section (4) was 230 (out of a theoretical maximum of 300; see coloured filled boxes in Suppl. Mat. Figure 2 heatmaps). Not all leaf classes and/or sections were present at each period and depth, with the exception of the basal part of intermediary and external leaves (Suppl. Mat. Figure 2). Internal younger leaves were shorter than intermediary and external leaves. Internal leaves were absent at $20 \mathrm{~m}$ depth in November 2017 and 10 and $15 \mathrm{~m}$ depth in August 2018. Leaves were shorter at $30 \mathrm{~m}$ depth and were shorter in November after the renewal of the leaf bundle (Bay 1984). The ratio of the leaf class-section DMSP and DMSO contents to the seagrass leaf bundle average contents (Suppl. Mat. Table 1) ranged, for the basal sections (0-10, $10-20,0-20 \mathrm{~cm}$ ) of external leaves, between 0.77 and 0.80 . It ranged between 0.98 and 1.15 for the basal sections of intermediary leaves, with the best leaf section to bundle match for the 10-20 cm section (1.06 for DMSP, 0.98 for DMSO), then the 0-20 cm section (1.09 for DMSP, 1.04 for DMSO).

DMSP and DMSO contents in the basal section $(0-20 \mathrm{~cm}$ for years 2015-2016, 0-10 cm for years 2016-2017 and years 2017-2018) of P. oceanica rank 3-4 leaves showed seasonal and interannual variability at all depths from 10 to $30 \mathrm{~m}$ (Fig. 2, Suppl. Mat. Figure 3A, B). The variability of DMSP and DMSO contents with depth was less, in agreement with the observations made for $P$. oceanica 2017-2018 compartmentalisation study. DMSP and DMSO contents were higher in winter, lower in summer-autumn. Of the 87 sample average values, the maximum for DMSP was measured in February 2017 at $30 \mathrm{~m}$ depth $\left(233 \mu\right.$ mol. $\mathrm{g}_{\mathrm{fw}}{ }^{-1}$; mean, $\left.n=2\right)$ and the minimum in May 2018 at $15 \mathrm{~m}$ depth $\left(50 \mu \mathrm{mol}_{\mathrm{g}} \mathrm{g}_{\mathrm{fw}}{ }^{-1} ; n=1\right)$. For DMSO, the maximum was measured in February 2017 at $20 \mathrm{~m}$ depth $\left(12.3 \pm 1.3 \mu\right.$ mol. $\mathrm{g}_{\mathrm{fw}}{ }^{-1}$; mean $\left.\pm \mathrm{SD}, n=3\right)$ and the minimum in July 2016 at $10 \mathrm{~m}$ depth $\left(1.5 \mu\right.$ mol. $\mathrm{g}_{\mathrm{fw}}{ }^{-1}$; mean, $\left.n=2\right)$. The minimum (14.6 $\mu \mathrm{mol}: \mu \mathrm{mol}$; mean, $n=2)$ and maximum (55.9 $\mu \mathrm{mol}: \mu \mathrm{mol}$; mean, $n=2$ ) of the DMSP:DMSO ratio were observed in May and July of year 2016, at depths 30 and $10 \mathrm{~m}$, respectively. The DMSP:DMSO ratio value varied little compared to the DMSP and DMSO contents, and was to some extend lower in 2017 and 2018 at all depths except 30 m (Fig. 2, Suppl. Mat. Figure 3C). The average 

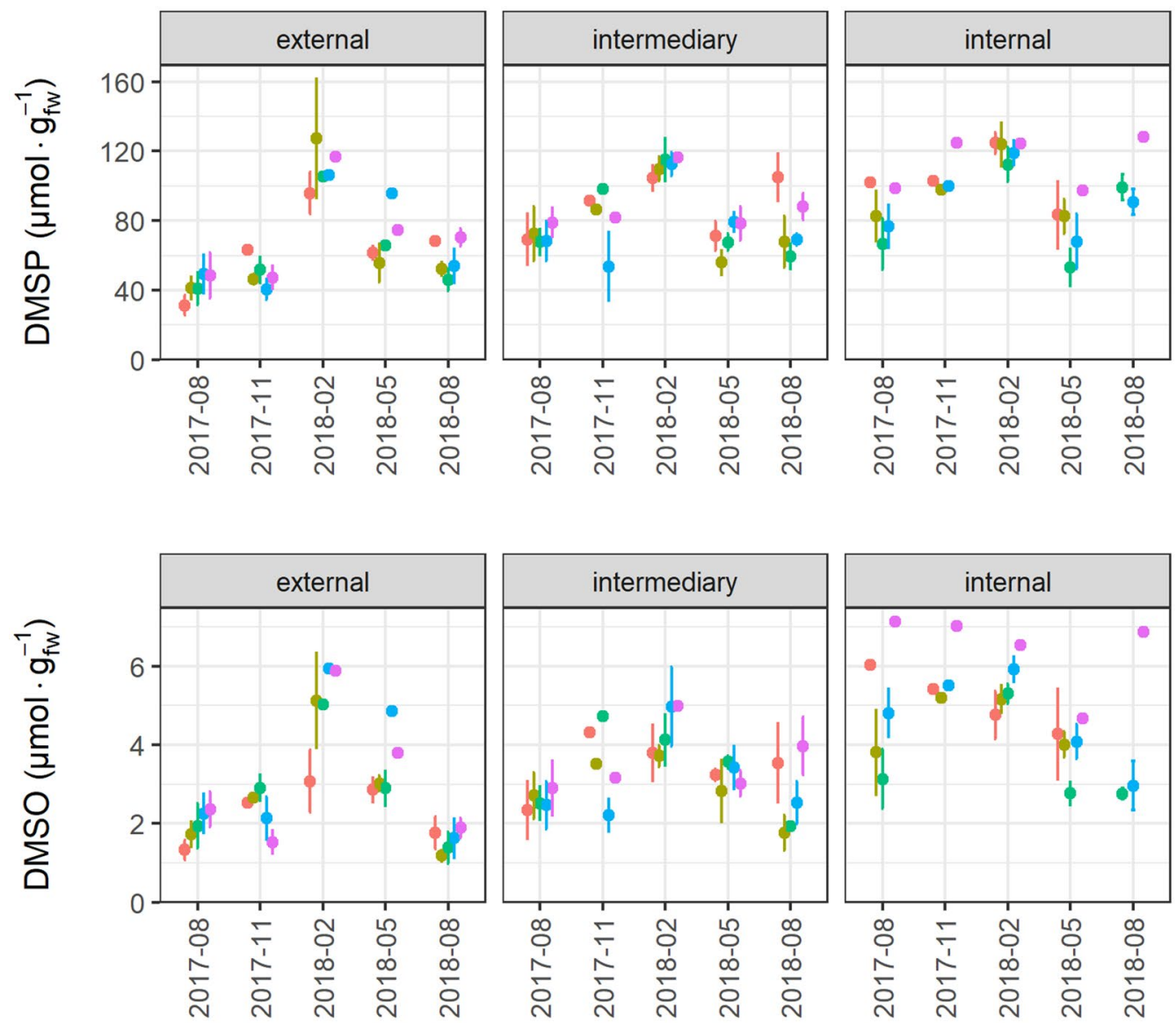

depth

$-10 \mathrm{~m}$

$\rightarrow 15 \mathrm{~m}$

$\rightarrow 20 \mathrm{~m}$

$-25 \mathrm{~m}$

$-30 \mathrm{~m}$
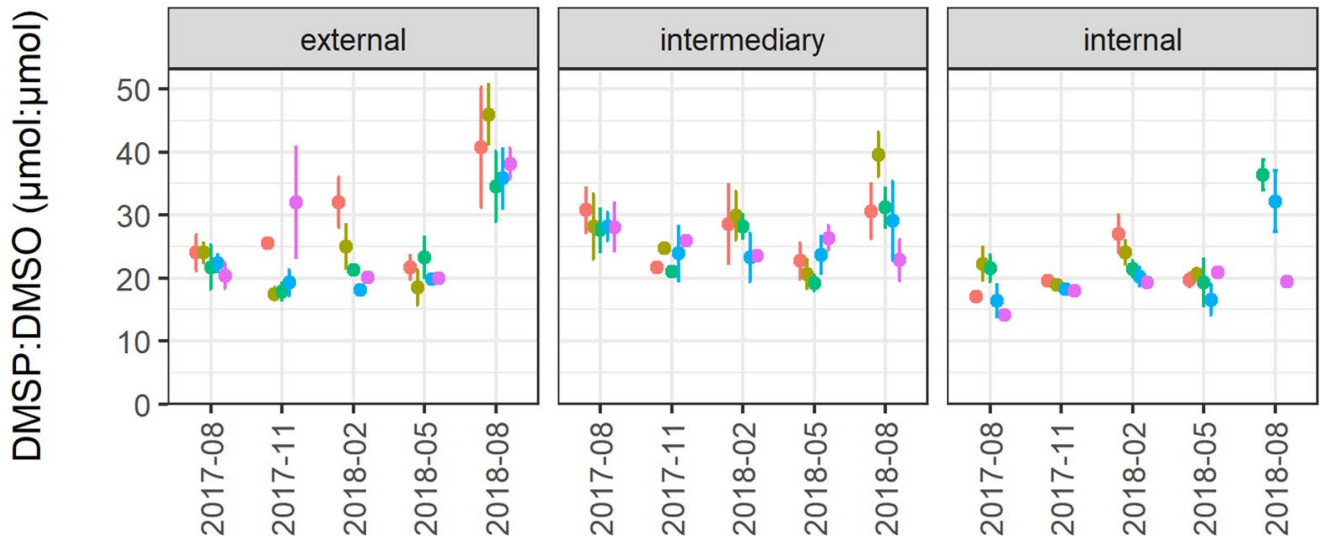

Fig. 1 DMSP content $\left(\mu \mathrm{mol} . \mathrm{g}_{\mathrm{fw}}{ }^{-1}\right)$, DMSO content $\left(\mu \mathrm{mol} . \mathrm{g}_{\mathrm{fw}}{ }^{-1}\right)$ and DMSP:DMSO ratio value $(\mu \mathrm{mol}: \mu \mathrm{mol})$ in Posidonia oceanica leaf samples $(n=230)$ grouped by factor variables leaf class, period and depth $(\mathrm{m})$. Data are averages (mean $\pm \mathrm{SD}$ ) of $P$. oceanica $10 \mathrm{~cm}$ long

DMSP:DMSO ratio value of the 87 samplings performed between 10 and $30 \mathrm{~m}$ deep from spring 2015 to summer 2018 was $28.2 \pm 7.2 \mu$ mol: $\mu$ mol (mean $\pm \mathrm{SD}, n=87$ ). The season effect on the organosulfur compounds in P. oceanica rank 3-4 leaf basal sections was evident when data were averaged by meteorological seasons and years, excluding leaf sections ( $n=1-4$ sections, depending on the length of the leaves). The three leaf classes are: internal (rank 1-2 on average), intermediary (rank 3-4 on average) and external (rank $4-5$ on average).

the depth (DMSP: $F(3,80)=14.76, p=9.8 \times 10^{-8}$; DMSO: $F(3,80)=13.66, p=2.8 \times 10^{-7}$; Fig. 3). DMSP decreased from autumn-winter to summer. DMSO decreased from winter to summer, autumn showing transitional values. The interannual variability of organosulfur compound contents (DMSP: $F(3,80)=18.43, p=3.5 \times 10^{-9}$, DMSO: 
$F(3,80)=6.77, p=0.0004)$ resulted, for DMSP, from differences in autumn and spring between the years 2015-16 and 2017-18; between 2015 and 2018 for DMSO. The DMSP:DMSO ratio value remained relatively constant over time, with a slight increase from winter to summerautumn $(F(3,80)=5.06, p=0.003)$ and interannual variability measured mainly between the years 2016 and 2017-18 $\left(F(3,80)=8.60, p=5.1 \times 10^{-5}\right)$. These annual differences in the DMSP:DMSO ratio, when considered on a seasonal basis, resulted in systematically higher values for the year 2016 ( $p<0.05$ for summer and autumn), followed by the years 2015 and $2017-18$.

DMSP and DMSO contents measured in Z. marina and C. nodosa whole leaf bundles (Table 1) were 1-3 orders
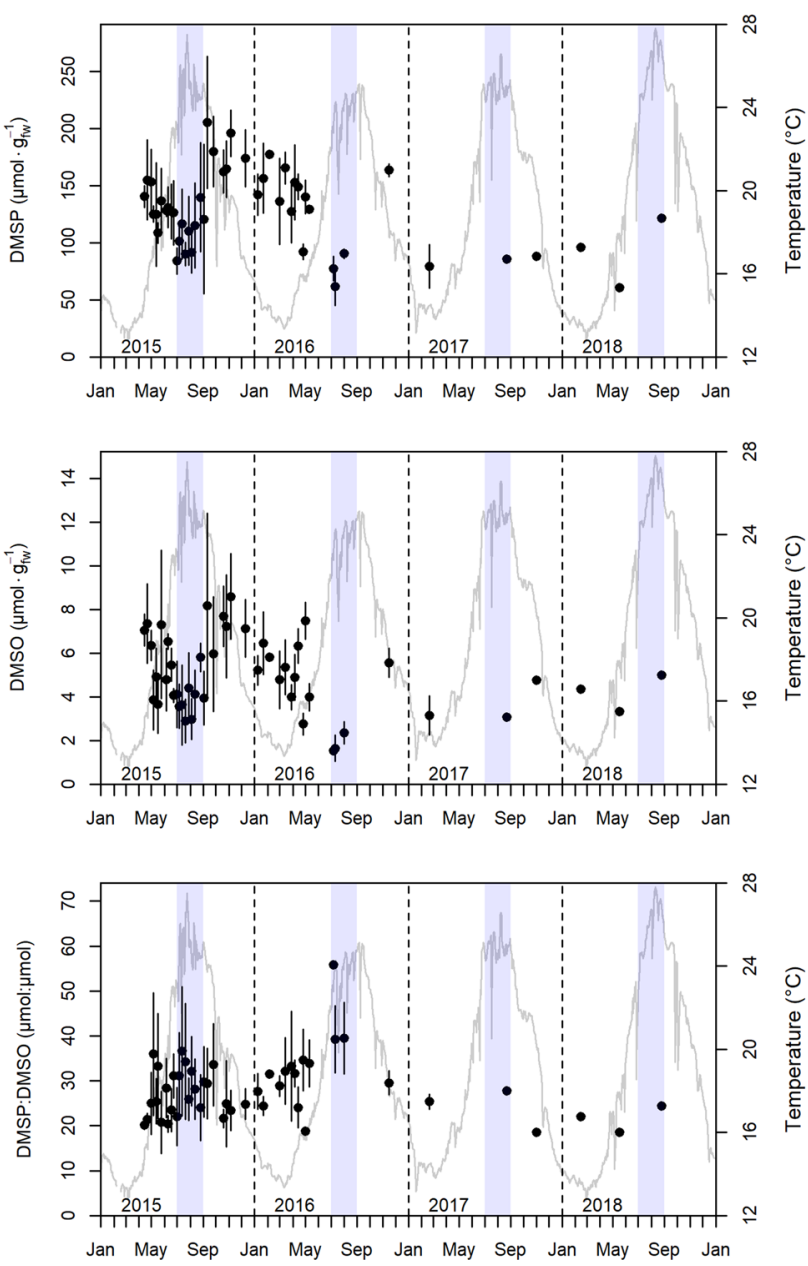

Fig. 2 Seasonal and interannual variability of DMSP content ( $\mu$ mol. $\mathrm{g}_{\mathrm{fw}}{ }^{-1}$ ), DMSO content $\left(\mu \mathrm{mol} . \mathrm{g}_{\mathrm{fw}}{ }^{-1}\right.$ ) and DMSP:DMSO ratio value $(\mu \mathrm{mol}: \mu \mathrm{mol})$ in the basal section $(0-20 \mathrm{~cm}$ for years 2015-2016, 0-10 cm for years 2016-2017 and years 2017-2018) of Posidonia oceanica rank 3-4 leaves, sampled at $10 \mathrm{~m}$ depth. P. oceanica data (dots) are mean $\pm \mathrm{SD}(n=1-3)$. The light grey line is the daily mean temperature (one record every 10 or $60 \mathrm{~min}$ ). Bright coloured rectangles highlight the data for July and August. of magnitude lower than in P. oceanica leaf samples (all leaf classes and sections of the three sampling designs combined). They varied by a factor of 7 between minimum and maximum contents for DMSP, from $0.02 \mu$ mol. $_{\mathrm{f}_{\mathrm{w}}}{ }^{-1}$ (Port Laso, France) to $0.13 \mu \mathrm{mol}^{\mathrm{g}} \mathrm{fw}^{-1}$ (Kernisi, France); by a factor of 15 for DMSO, from $0.04 \mu$ mol. $_{\mathrm{fw}_{\mathrm{f}}}{ }^{-1}$ (Krisitneberg, Sweden) to $0.58 \mu \mathrm{mol} . \mathrm{g}_{\mathrm{fw}}{ }^{-1}$ (Kernisi, France). The levels of organosulfur compounds in $C$. nodosa were within the range of variation of the levels in $Z$. marina. The inter-sites variability did not follow a geographical pattern.

Overall, the general scatterplot of DMSP and DMSO contents for all $P$. oceanica leaf samples collected between years 2015 and 2018 showed a clear linear relationship between the two compounds $\left(\mathrm{R}_{1}=0.40, F(1,412)=322.9\right.$, $p<2.2 \times 10^{-16}$; Suppl. Mat. Figure 4); and similarly for $Z$. marina and $C$. nodosa (Suppl. Mat. Figure 5). The relationship in $P$. oceanica was modelled from measurements performed on different sections of the different leaf classes-ranks, sampled along a depth gradient at different seasons over several years, in a non-disturbed meadow. Therefore, we argue this is representative of a P. oceanica meadow in its biological/physiological complexity. The slope of the median regression was 0.035 , i.e. the amount of DMSO in P. oceanica leaf tissues was equivalent to $3.5 \%$ that of DMSP.

Seawater temperatures in July and August, especially at the shallowest depth of $10 \mathrm{~m}$, were up to $4{ }^{\circ} \mathrm{C}$ higher in 2018 compared to 2016 (Fig. 2), most probably in response to the European 2018 heatwave (Liu et al. 2020). Predictions for DMSP and DMSO contents in P. oceanica intermediary leaf basal section from median regression with restricted cubic spline function was minimal for a temperature of $24.5^{\circ} \mathrm{C}$ (DMSP: $b_{1}=-29.21, t(9)=-4.14$, $p=0.0025$ and $b_{2}=20.48, t(9)=5.79, p=0.0003$; DMSO: $b_{1}=-0.94, t(9)=-2.54, p=0.032$ and $b_{2}=0.87, t(9)=2.48$, $p=0.035$; Fig. 4). This temperature corresponded to the average value at $10 \mathrm{~m}$ depth for 2016 , the coldest summer water temperature recorded at that depth over the survey. The averages of July and August temperatures at $20 \mathrm{~m}$ depth were relatively similar between years, close to the value of $24.5^{\circ} \mathrm{C}$. At temperatures lower (for $30 \mathrm{~m}$ depth) or higher (for years 2015, 2017 and 2018 at $10 \mathrm{~m}$ depth) corresponded higher DMSP and DMSO contents in $P$. oceanica rank 3-4 leaf basal section. P. oceanica relative growth rate $\left(\mathrm{d}^{-1}\right)$ response to experimental warming, fitted with the temperature cardinal model with inflexion (Savva et al. 2018), mirrored DMSP and DMSO model trends. The curvature of the median regression model prediction, convex for the DMSP:DMSO ratio $\left(b_{1}=3.17, t(9)=1.11\right.$, $p=0.294$ and $b_{2}=-3.01, t(9)=-0.85, p=0.420$; Fig. 4), showed maximum value for the depth $10 \mathrm{~m}$ in 2016 . The increase of DMSP and DMSO contents with increasing temperature was particularly evident when considering 

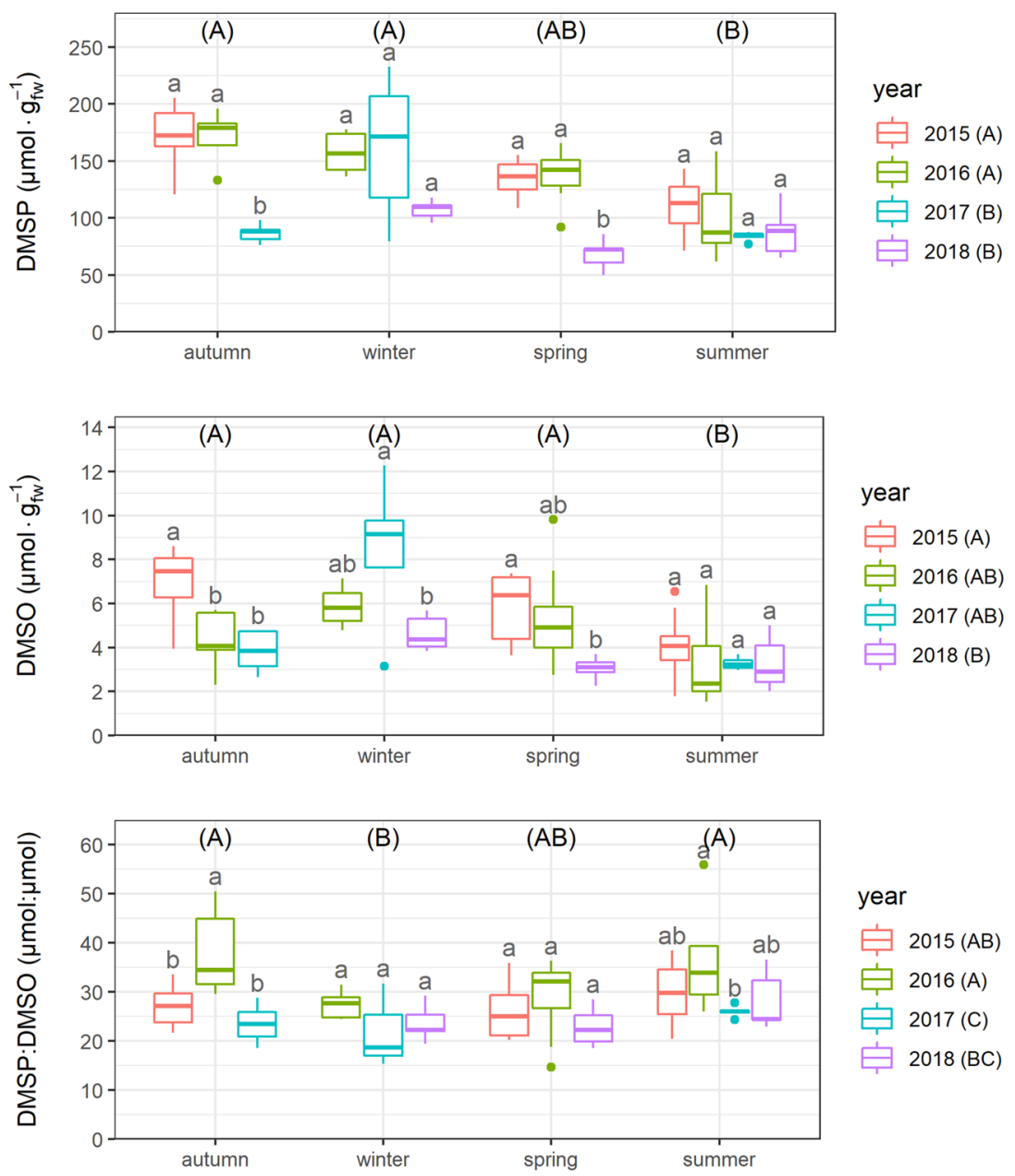

Fig. 3 Boxplots [median (bold line); Q1 and Q3 (boxes), ranges (whiskers) and outliers (dots)] of seasonal and interannual variability of DMSP content $\left(\mu \mathrm{mol}_{\mathrm{fw}}{ }^{-1}\right)$, DMSO content $\left(\mu \mathrm{mol}_{\mathrm{g}} \mathrm{g}_{\mathrm{fw}}{ }^{-1}\right)$ and DMSP:DMSO ratio value ( $\mu \mathrm{mol}: \mu \mathrm{mol})$ in the basal section $(0-20 \mathrm{~cm}$ for years 2015-2016, 0-10 cm for years 2016-2017 and years 20172018) of Posidonia oceanica rank 3-4 leaves, all 10 to $30 \mathrm{~m}$ depths considered ( $n=5-16$ dates and depths on a data set of 87 samplings). Seasons are meteorological seasons. The winter boxplot values for
2016 are calculated from data for December 2015, January 2016 and February 2016 (same for winter boxplot values for 2017 and 2018). Upper case letters in brackets represent differences ( $p<0.05$, two-way ANOVA and Tukey's post hoc test) between seasons (in the graphic windows) or years (in the legends). Lower case letters represent differences $(p<0.05$, one-way ANOVA and Tukey's post hoc test) between years, for each seasons.
$10 \mathrm{~m}$ depth data only (DMSP: $b=17.11, t(2)=5.41$, $p=0.033$; DMSO: $b=1.17, t(2)=25.29, p=0.0016$; Fig. 4). An increase in average temperature in July and August of $3{ }^{\circ} \mathrm{C}$ corresponded to a doubling of the DMSP and DMSO contents remaining in summer (i.e. at the end of the autumn/winter to summer seasonal decrease of molecule contents in leaves). The trend for the DMSP:DMSO ratio ( $b=-7.21, t(2)=-3.05, p=0.093$; Fig. 4) was opposite to that of the individual organosulfur compounds. The opposite slopes and curvatures of the models meant that the decrease in DMSO from recorded temperature extrema to $24.5^{\circ} \mathrm{C}$ was greater than that of DMSP.

\section{Discussion}

This study confirms that $P$. oceanica is a top producer of DMSP and DMSO among marine photoautotrophs, with leaf contents ranging from 25 to $265 \mu \mathrm{mol} . \mathrm{g}_{\mathrm{fw}}{ }^{-1}$ for DMSP and from 1.0 to $13.9 \mu \mathrm{mol}_{\mathrm{f}} \mathrm{g}^{-1}$ for DMSO. This observation was in line with recent research on that species (Borges and Champenois 2015, 2017; Champenois and Borges 2019; Richir et al. 2020). High DMSP contents, of the same order of magnitude as in P. oceanica, were reported in Chlorophyta, mainly of the genus Ulva with up to $128 \mu \mathrm{mol} . \mathrm{g}_{\mathrm{fw}}{ }^{-1}$ in $U$. lactuca (Van Alstyne and Puglisi 2007; Van Alstyne et al. 2007); and for DMSO, up to $16.7 \mu \mathrm{mol} . \mathrm{g}_{\mathrm{fw}}{ }^{-1}$ in natural marine phytoplankton 
Fig. 4 Relationships between DMSP content $\left(\mu \mathrm{mol}_{\mathrm{ffw}}{ }^{-1}\right)$, DMSO content $\left(\mu \mathrm{mol} . \mathrm{g}_{\mathrm{fw}}{ }^{-1}\right)$ or DMSP:DMSO ratio value $(\mu \mathrm{mol}: \mu \mathrm{mol})$ in the basal section $(0-20 \mathrm{~cm}$ for years 2015-2016, 0-10 cm for years 2016-2017 and years 20172018) of Posidonia oceanica rank 3-4 leaves with temperature, for depths 10, 20 and $30 \mathrm{~m}$ (three left graphics) or depth $10 \mathrm{~m}$ only (three right graphics). Numbers 5 to 8 represent years 2015 to 2018 , respectively. $P$. oceanica and temperature data are mean $\pm \mathrm{SD}(n=1-8$ for $P$. oceanica; $n=16$ daily average values for temperature) for July and August. Temperature data are values greater than or equal to their respective 75th percentile for that period. Blue lines are predictions from median regression with restricted cubic spline function (three left graphics) or best linear-fits (three right graphics). The red line is $P$. oceanica relative growth rate $\left(\mathrm{d}^{-1}\right)$ response to experimental warming, fitted with the temperature cardinal model with inflexion (Savva et al. 2018)
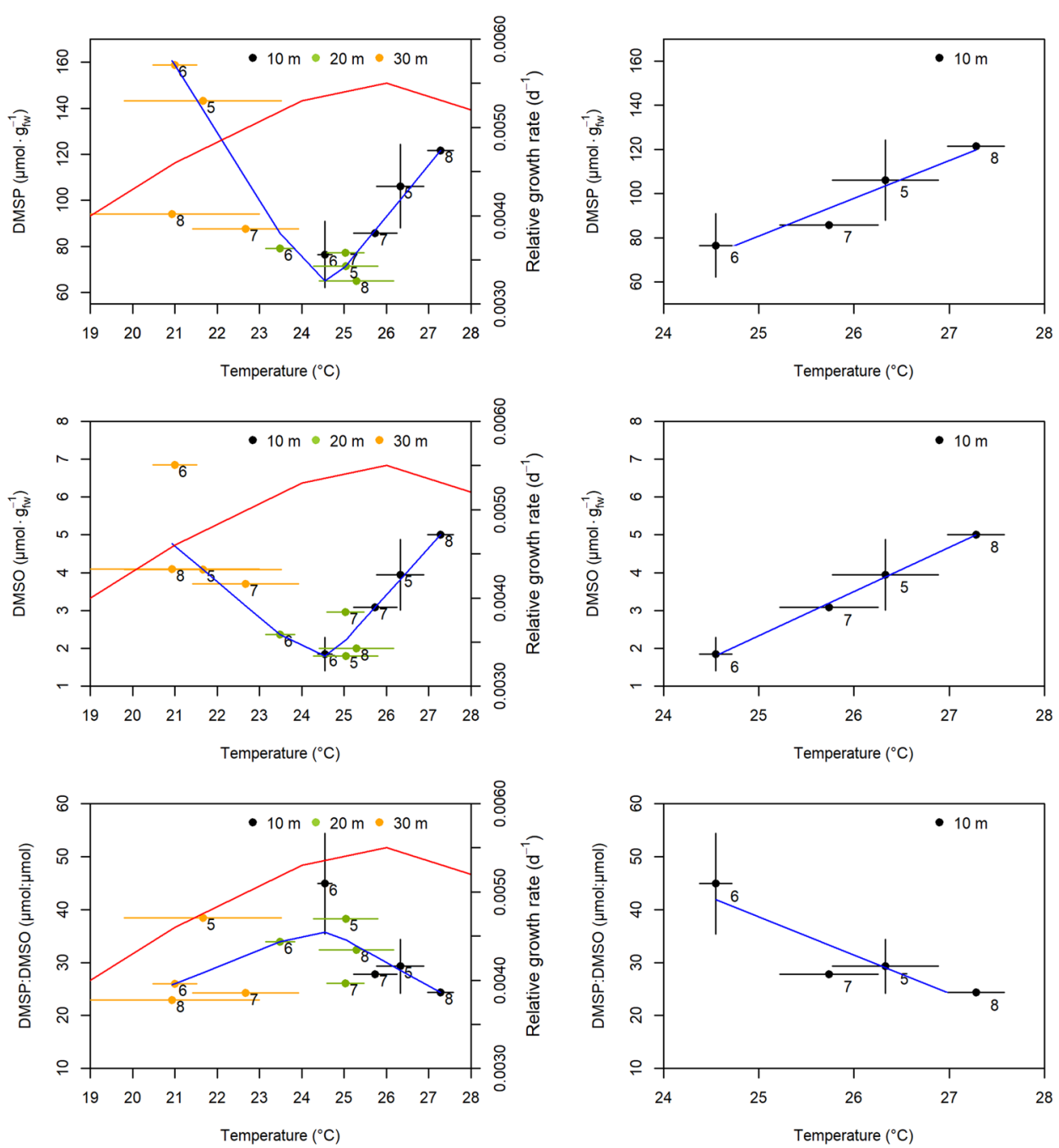

communities from warm waters (Simó and Vila-Costa 2006; Richir et al. 2020). The scientific literature on DMSP in seagrasses is scarce; so far, inexistent for DMSO. DMSP measured in the epiphyte-leaf complex of $H$. wrightii, $S$. filiforme (Dacey et al. 1994) and Z. marina (White 1982) was very low compared to $P$. oceanica $\left(\leq 3.3 \mu \mathrm{mol}_{\mathrm{g}}{ }_{\mathrm{fw}}{ }^{-1}\right.$, after transformation from dry to fresh weight content for Z. marina, considering a moisture content of $75 \%$ ); and the production of DMSP by non-epiphytized leaves was two-to-three orders of magnitude lower in $T$. testudinum $\left(0.18,0.21 \mu \mathrm{mol} . \mathrm{g}_{\mathrm{fw}}{ }^{-1}\right.$; Dacey et al. 1994) and Z. noltei $\left(0.14 \mu \mathrm{mol}_{\mathrm{g}} \mathrm{g}_{\mathrm{fw}}{ }^{-1}\right.$; Jonkers et al. 2000) than in P. oceanica. This difference in DMSP content with $P$. oceanica was similar for C. nodosa $\left(0.07 \mu \mathrm{mol}_{\mathrm{g}} \mathrm{g}_{\mathrm{fw}}{ }^{-1}\right)$ and Z. marina $\left(0.02-0.12 \mu \mathrm{mol}_{\mathrm{f}} \mathrm{g}_{\mathrm{w}}{ }^{-1}\right)$ leaf bundles in the present study; and DMSO content differed by one order of magnitude in average for $C$. nodosa $\left(0.25 \mu \mathrm{mol}_{\mathrm{g}} \mathrm{g}_{\mathrm{fw}}{ }^{-1}\right)$ and $Z$. marina $\left(0.04-0.39 \mu \mathrm{mol}_{\mathrm{f}}{ }_{\mathrm{fw}}{ }^{-1}\right)$. High $\operatorname{DMSP}(\mathrm{O})$ production may, therefore, not be a general characteristic shared among seagrasses, as previously reported for Chlorophyta (Van
Alstyne 2008). The amount of DMSO relative to that of DMSP in P. oceanica leaf tissues was $3.5 \%$. This value was similar to that of $3.8 \%$ previously reported by Richir et al. (2020) on their reduced data set (less than one third of the present data set) and to that of 1.6-4.0\% reported by Husband and Kiene (2007) for S. alterniflora. DMSP and DMSO contents were also correlated in C. nodosa and Z. marina confirming the finding of Richir et al. (2020) that DMSP and DMSO are correlated in marine autotrophs (phytoplankton, macroalgae, magnoliophytes).

Higher DMSP and DMSO contents in young leaf tissues decreased continuously with the growing cycle, which was the aging of the leaf bundle. This seasonal feature, reported by Richir et al. (2020) for P. oceanica third (rank 3) leaves was confirmed in the present study, regardless of the year, depth or leaf tissue. Contents of photosynthetic pigments that are essential compounds in photoautotrophs also decrease with leaf tissue aging in seagrasses, e.g. T. testudinum (Enríquez et al. 2002). Several processes can explain this decrease in organosulfur 
compound contents: young leaf tissues benefit from an initial stock of molecules that decreases (dilution and metabolism) with aging; leaves produce these compounds continuously but at a rate too low to compensate for their dilution and metabolism; minimum contents in late summer early autumn prior annual renewal of the leaf bundle result from translocalisation and recycling of essential elements including $\mathrm{S}$ through rhizomes from old, senescent, decaying adult leaves. S. alterniflora is the largest DMSP producer among Spartina species (Otte et al. 2004; Rousseau et al. 2017) and the second among coastal higher plants after $P$. oceanica. In $P$. oceanica, the plant size, age and biomass are directly related. The production of DMSP and DMSO decreases with aging, therefore, with the increase of biomass. The experimental stimulation with nitrogen supply of $S$. alterniflora biomass production led to the dilution of DMSP content (Otte and Morris 1994). Of the hypotheses listed above for P. oceanica, DMSP and DMSO dilution with biomass increase was more likely to occur. Finally, results of the present study showed that intermediary leaves [rank 3-4; i.e. inserted between the recently grown internal leaves (rank 1-2) and the oldest external ones, possibly senescent and ready to fall (rank 5-6, for an average number of 6 leaves per $P$. oceanica bundle)], with an organosulfur molecule content similar to the average value calculated for the seagrass leaf bundle, appeared to be the best choice of sample material to study DMSP and DMSO in that species. Observations from this study and previous work (Romero et al. 2007; Luy et al. 2012; Richir et al. 2020), therefore, justify the election of intermediary, rank 3-4 leaves as representative tissue to study the plant biology. In addition, sampling only intermediary leaves above their meristem is non-destructive and allows for plant survival (Gobert et al. 2020).

Temperature could play a (indirect) role in the observed seasonal trends of DMSP and DMSO contents in P. oceanica leaf tissues. There is little/no data to our best knowledge on the relationship between DMSP and DMSO production in marine coastal higher plants and temperature, except in Richir et al. (2020). These authors reported weak to modest relationships of $P$. oceanica leaf organosulfur compound contents with temperature. In algae, the negative relationship between DMSP content and temperature (Karsten et al. 1992; Lyons et al. 2010) suggested a cryoprotectant function (reviews on DMSP functions in: Otte et al. 2004; Stefels et al. 2007; Van Alstyne 2008). Such a function is unlikely in $P$. oceanica because that species, endemic of the Mediterranean, grows in temperate environmental conditions (Boudouresque and Meinesz 1982) and must not cope with cold water temperatures but with global warming (Duarte et al. 2018; Darmaraki et al. 2019). Average DMSP and DMSO contents according to the year and depth in July-August were the lowest for a narrow range of temperatures, between
23.5 and $25.5^{\circ} \mathrm{C}$. Temperatures lower (for $30 \mathrm{~m}$ depth) or higher (for years 2015, 2017 and 2018 at $10 \mathrm{~m}$ depth) corresponded with higher summer average DMSP and DMSO contents. Hendriks et al. (2017) experimentally tested the effect of light availability and warm temperature $\left(29-30{ }^{\circ} \mathrm{C}\right)$ on $P$. oceanica growth and photosynthetic activity. Temperature had a negative effect on growth. Low light availability also negatively affected photosynthetic performance. DMSP and DMSO contents in P. oceanica seemed, like in S. alterniflora (Otte and Morris 1994), to be related to the growth and biomass production of the plant (dilution and resource allocation). Considering that organosulfur compound contents would decrease as a result of improved plant growth under optimal environmental conditions, the relationships modelled in the present study reflected the negative impact of higher temperature on the plant biomass production at low depth $(10 \mathrm{~m})$ and the combined negative effect of low light availability but positive effect of increased temperature on biomass production in deeper water $(30 \mathrm{~m})$. In addition, the relative growth rate response of $P$. oceanica to experimental warming modelled in Savva et al. (2018) mirrored the relationships between DMSP and DMSO summer contents with temperature. Based on these observations, the next work should focus on the direct effect of primary production in contrasted environmental conditions on the contents of DMSP and DMSO.

The trend for the DMSP:DMSO ratio in relation to summer temperature, depending on the year and depth, was opposite to that of the organosulfur compounds, with maximum at $24.5{ }^{\circ} \mathrm{C}$ and a decrease towards recorded temperature extrema. DMSP, DMSO, DMS, acrylate and methane-sulfinic acid constitute a cascade reaction system against oxidative stress in the algal cell (Sunda et al. 2002; Deschaseaux et al. 2014). In yellowing (senescence) and herbicide-treated S. alterniflora (Husband and Kiene 2007; Husband et al. 2012), and in cordgrasses collected from areas affected by sudden dieback, grazing and wrack deposition (McFarlin and Alber 2013), DMSP was converted to its oxidation product DMSO resulting in a lower DMSP: DMSO ratio (published as DMSO: DMSP ratio by the authors) compared to healthy unstressed plants. Conversely, at environmental optima (e.g. light and temperature), P. oceanica biomass production would be maximum, its physiological status globally very good, and the higher DMSP: DMSO ratio value an indicator of this overall good health status (corresponding to maximum growth rate; Savva et al. 2018). The average DMSP: DMSO ratio value of $28.2 \pm 7.2 \mu \mathrm{mol}: \mu \mathrm{mol}$ in P. oceanica basal section of rank 3-4 leaves $(\min =14.6 \mu \mathrm{mol}: \mu \mathrm{mol}, \max =55.9 \mu \mathrm{mol}: \mu \mathrm{mol})$ was close to that of $29.2 \pm 9.0 \mu \mathrm{mol}: \mu \mathrm{mol}$ reported by Richir et al. (2020). Just as the DMSP and DMSO contents of healthy Z. marina and $C$. nodosa leaf bundles were low compared to $P$. oceanica, so were their ratios. In different 
marine algal taxa grown under axenic conditions and used for DMSO reduction studies, Spiese et al. (2009) reported $\mathrm{DMSP}_{\mathrm{p}}: \mathrm{DMSO}_{\mathrm{p}}$ ( $_{\mathrm{p}}$ for particulate) ratios (published as $\mathrm{DMSO}_{\mathrm{p}}: \mathrm{DMSP}_{\mathrm{p}}$ ratio by the authors) varying by four order of magnitude, from 3.3 for Thalassiosira oceanica to 1870 for Isochrysis galbana. In response to salinity stress, the DMSP $_{\mathrm{p}}: \mathrm{DMSO}_{\mathrm{p}}$ ratio increased in laboratory batch cultures of the two phytoplankton species Phaeocystis globosa and Heterocapsa triquetra (Speeckaert et al. 2019); and in Fe-limited T. oceanica phytoplanktonic cells, the higher $\mathrm{DMSP}_{\mathrm{p}}: \mathrm{DMSO}_{\mathrm{p}}$ ratio relative to Fe-sufficient cells was explained by the net loss of DMSO via its enzymatic reduction to more lipophilic DMS (Bucciarelli et al. 2013). The evolution of DMSP and DMSO levels, and thus their ratio in marine primary producers exposed to environmental stresses, and the relevance of its use as a stress indicator therefore requires a thorough knowledge of the productiontransformation kinetics of these compounds, specific to the species and the stressor.

Inter-annual variations of DMSP at $10 \mathrm{~m}$ depth (and shallower) where the temperature can reach and exceed the physiological maximum of $P$. oceanica might indicate that the organosulfur compound contents were directly involved in the response of the plant to heat stress. Stress, including heat-stress leads to the enhanced accumulation of toxic compounds in cells, among them reactive oxygen species (ROS; Suzuki and Mittler 2006; Kotak et al. 2007) efficiently scavenged by DMSP and DMSO (Sunda et al. 2002). McLenon and DiTullio (2012) experimentally observed an increase of DMSP concentration in Symbiodinium cells isolated from the cnidarian Acacia pulchella when maintained at $33{ }^{\circ} \mathrm{C}$, suggesting an antioxidant function of DMSP under temperature-induced oxidative stress. Experimental temperature increase had, in contrast, no or little effect on antioxidant capacity and DMSP concentrations in Symbiodinium cells and their host sea anemone Entacmaea quadricolor (Deschaseaux et al. 2018). An end of century temperature scenario $\left(23^{\circ} \mathrm{C}\right)$ had no significant effects on the concentrations of DMSP and DMS in Amphidinium carterae cultured dinoflagellates (Li et al. 2020). However, two ecotypes of the terrestrial plant Arundo donax from warm sub-humid (Central Italy) and hot semi-arid (Morocco) habitats (existing environmental scenarios) showed differences in DMSP leaf content, with DMSP (and isoprene) increase under the moderate stress conditions of the second habitat (Haworth et al. 2017). These observations, different but not contradictory (no DMSP decrease), seem to indicate a potential direct link between heat stress, ROS and the dynamics of $\operatorname{DMSP}(\mathrm{O})$ and DMS in plants and algae.

DMSP content in seagrasses could be explored in relation to phylogenetic history. In cordgrasses of the genus Spartina, the physiological ability to biosynthesize DMSP was explained phylogenetically (Rousseau et al. 2017). $P$. oceanica and T. testudinum belong to two different lineages, respectively the Posidoniaceae/Zosteraceae and the Marine Hydrocharitaceae viz. Enhalus/Thalassia (according to the revised classification of Dilipan et al. 2018); but their belonging to different lineages is probably not the explanation for the measured differences in leaf DMSP production. Indeed, low DMSP content was measured in $Z$. marina $(0.04-0.39 \mu \mathrm{mol}$. $\left.\mathrm{g}_{\mathrm{fw}}{ }^{-1}\right)$ and Z. noltei (0.14 $\mu$ mol.g ${ }_{\mathrm{fw}}{ }^{-1}$; Jonkers et al. 2000), two species that belong like P. oceanica to the Posidoniaceae/ Zosteraceae lineage. Another useful method of categorizing seagrasses is on the basis of their growth forms, from small plants with thin leaves (e.g. Halodule) to large plants with thick leaves (e.g. Posidonia). This seagrass functional form model proposed by Walker et al. (1999) is ultimately related to seagrass rhizome turnover: rapid rhizome turnover in the smaller seagrass genera and slower turnover of persistent rhizomes in the larger seagrasses. Consistent with rhizome turnover rate is leaf turnover rate, more rapid in smaller seagrasses than in larger species (Duarte 1991; Duarte and Chiscano 1999; Walker et al. 1999). The two Zostera species share with T. testudinum (and to a lesser extend with $C$. nodosa) a rapid turnover rate of their tissues when compared to $P$. oceanica (Duarte 1991; Duarte and Chiscano 1999). Slower turnover rates allow higher buildup of secondary compounds including predator deterrents, thus reducing palatability to grazers (Walker et al. 1999). High secondary metabolite DMSP production by the slow-turnover species $P$. oceanica has been proposed as a protective mechanism against grazing (Richir et al., 2020; Borges and Champenois, 2015).

Grazing plays a central role in seagrass ecology (Heck and Valentine 2006; Valentine and Duffy 2006). Depending on time and location, between $\sim 3$ and $100 \%$ of seagrass net primary production enters food webs via the grazing pathway (Heck and Valentine 2006). As an example, 50-100\% of the aboveground biomass of T. testudinum can be consumed by the purple urchin Lytechinus variegates (Valentine and Heck 1991) and 40-70\% of $P$. oceanica leaf production can be grazed by the herbivorous fish Sarpa salpa (Tomas et al. 2005; Prado et al. 2007). Peirano et al. (2001) reported, for the three main grazers of $P$. oceanica, a maximum grazing on leaves in September and June for S. salpa, in March for the urchin Paracentrotus lividus, whereas it was irregular for the isopods Idotea spp.; and Tomas et al. (2005) observed abundant $S$. salpa grazing marks ( $>55 \%$ of collected shoots) all year round, and higher $P$. lividus bites in winter/spring. Grazing pressure, which may be seasonal depending on the herbivorous behaviour of the species, occurs throughout the annual growth cycle of the seagrass. Vergés et al. (2007) experimentally showed that organic extracts of $P$. oceanica (secondary metabolites, including phenolics) deterred grazers from feeding. However, it is worth to say that seagrass deterrence response to grazers is not unique, with grazer identity and density, and seagrass species and leaf tissue all 
playing important roles in deterrent production (Steele and Valentine 2015). Herbivory on seagrasses is an important process whose potential effect on the production of the secondary metabolites DMSP and DMSO remains to be investigated; especially considering the grazer deterrent function of DMSP and its cleavage products (DMS, acrylic acid) discussed in other marine photoautotrophs (Van Alstyne and Houser 2003; Otte et al. 2004; Fredrickson and Strom 2009).

A common trait to seagrasses is the need of osmoregulation in seawater. Seagrasses have developed several strategies for osmoregulation (Papenbrock 2012) including the synthesis of compatible osmolytes. DMSP is a compatible osmolyte used for osmoregulation by macroalgae and microalgae (Stefels et al. 2007), that can be advantageous in oligotrophic environments (e.g. Mediterranean coastal waters) compared to $\mathrm{N}$ containing compatible osmolytes such as betaine (Colmer et al. 1996; Kocsis and Hanson 2000). In P. oceanica, the increase of salinity leads to the synthesis of sugars and amino acids (Marín-Guirao et al. 2011a; Marín-Guirao et al. 2011b; Sandoval-Gil et al. 2012), but the synthesis of DMSP was not tested, which does not exclude that it could act as an osmolyte. Increased synthesis of amino acids is compatible with the one of DMSP, since in plants, methionine is usually a precursor of DMSP (Kocsis and Hanson 2000; Bullock et al. 2017). The fact that seagrasses have developed different strategies for osmoregulation is compatible with a strong variability of DMSP content among different seagrasses.

\section{Conclusion}

Recent work on P. oceanica and the present study demonstrated this seagrass species was the largest producer of DMSP and DMSO reported to date among coastal autotrophs, and most probably the major contributor to the dissolved DMS $(\mathrm{P}, \mathrm{O})$ pool in coastal waters of the oligotrophic Mediterranean. DMSP and DMSO production and content dynamics in $P$. oceanica were related to the plant biology/physiology, in particular to its growth cycle and productivity which varies over time (season, year) and with depth. Temperature would indirectly affect DMSP and DMSO content dynamics through direct effect on the plant biomass production, leading to the more or less rapid dilution of an initial stock of molecules concentrated in newly grown leaf tissues. Whatever the sampling conditions or the leaf tissue analysed, a notable characteristic was the constant ratio of the two molecule contents. Such a constant ratio was an indicator of a strong biochemical link between DMSP and DMSO. Now that we have a basic, in depth understanding of the natural variability of DMSP and DMSO in $P$. oceanica leaves, future work should focus on their biosynthetic pathways and metabolism in relationship to its growth cycle and productivity. DMSP (and DMSO) physiological functions are not fully elucidated, and it may vary among coastal higher plants. Although hypothetical, grazer deterrence seems to be a likely function in P. oceanica, whilst the antioxidant function-including against heat stress will require experimental testing. Current studies on sampling location and species comparison and the analysis of experimentally stressed plants will allow responding to some of the questions raised in this work.

Supplementary Information The online version contains supplementary material available at https://doi.org/10.1007/s00227-021-03961-5.

Acknowledgements This work was funded by the Fonds National de la Recherche Scientifique (FNRS) (Fellowship-Grant 1237018F and contract 2.4.637.10). Authors thank Pr R. Koenker from the Department of Economics, University College London, UK for his help in quantile regression. At the time of this study, J. Richir was a postdoctoral researcher at the FNRS. J. Richir current affiliation is Centre d'Ecologie et des Sciences de la Conservation (CESCO), Muséum national d'Histoire naturelle, Station de Biologie Marine, Concarneau, France. A. V. Borges is a research director at the FNRS. JdF was supported by NWO Open Competition \#ALWOP.203.

Author contributions JR: conceptualization, data curation, formal analysis, funding acquisition, investigation, validation, visualization, writing - original draft, writing - review and editing. WC: conceptualization, investigation, validation, writing - review and editing. JF: formal analysis, investigation, writing-review and editing. AVB: conceptualization, funding acquisition, methodology, resources, supervision, writing - review and editing.

Funding Funding was provided by F.R.S-FNRS for salary and material, and by the STARESO via the STARECAPMED program for fieldwork

Data availability $\operatorname{DMSP}(\mathrm{O})$ and temperature data are published alongside the paper (Mendeley Data repository, https://doi.org/10.17632/ y65hzhbfsk.1).

Code availability Out of scope.

\section{Declarations}

Conflicts of interest No conflict of interest.

Ethical approval Authors had all the necessary authorizations for seagrass sampling, and used a little invasive, non-destructive technique that ensures the post-regrowth of sampled tissues.

Consent to participate All authors consent to participate.

Consent for publication All authors and all institutions that provided funding and to which the authors belong consent to the publication of this study.

\section{References}

Asher E, Dacey JW, Ianson D, Peña A, Tortell PD (2017) Concentrations and cycling of DMS, DMSP, and DMSO in coastal and 
offshore waters of the Subarctic Pacific during summer, 20102011. J Geophys Res Ocean 122:3269-3286. https://doi.org/10. 1002/2016JC012465

Augier H (2007) Guide des fonds marins de Méditerranée. In: Prairies et pelouses sous la mer, delachaux et niestlé, p 258-299

Bay D (1984) A field study of the growth dynamics and productivity of Posidonia oceanica in Calvi Bay, Corsica, France. Aquat Bot 20:43-64

Bianchi TS (2007) Biogeochemistry of estuaries. Oxford University Press

Binard M (2017) Composantes météorologiques de la base de données océanographique RACE de STARESO (Baie de Calvi - Corse). Bull Société Géographique Liège 68:37-47

Borges AV, Champenois W (2017) Preservation protocol for dimethylsulfoniopropionate and dimethylsulfoxide analysis in plant material of the Mediterranean seagrass Posidonia oceanica, and reevaluation of dimethylsulfoniopropionate leaf content. Aquat Bot 143:8-10. https://doi.org/10.1016/j.aquabot.2017.08.004

Borges AV, Champenois W (2015) Seasonal and spatial variability of dimethylsulfoniopropionate (DMSP) in the Mediterranean seagrass Posidonia oceanica. Aquat Bot 125:72-79. https://doi.org/ 10.1016/j.aquabot.2015.05.008

Boudouresque CF, Meinesz A (1982) Découverte de l'herbier de posidonie. Cah Parc Natl Port-Cros 4:1-79

Boudouresque CF, Bernard G, Bonhomme P, Charbonnel E, Diviacco G, Meinesz A, Pergent G, Pergent-Martini C, Ruitton S, Tunesi L (2012) Protection and conservation of Posidonia oceanica meadows. RAMOGE and RAC/SPA Publisher, Tunis

Bucciarelli E, Ridame C, Sunda WG, Dimier-Hugueney C, Cheize M, Belviso S (2013) Increased intracellular concentrations of DMSP and DMSO in iron-limited oceanic phytoplankton Thalassiosira oceanica and Trichodesmium erythraeum. Limnol Oceanogr 58:1667-1679. https://doi.org/10.4319/lo.2013.58.5.1667

Buia MC, Gambi MC, Dappiano M (2004) Seagrass systems. Biol Mar Mediterr 10:133-183

Bullock HA, Luo H, Whitman WB (2017) Evolution of dimethylsulfoniopropionate metabolism in marine phytoplankton and bacteria. Front Microbiol 8:637. https://doi.org/10.3389/fmicb.2017. 00637

Cade BS, Noon BR (2003) A gentle introduction to quantile regression for ecologists. Front Ecol Environ 1:412-420

Challenger F, Simpson MI (1948) Studies on biological methylation. Part,X. I. I. A precursor of the dimethyl sulphide evolved by Polysiphonia fastigiata. Dimethyl-2-carboxyethylsulphonium hydroxide and its salts. J. Chem. Soc. 3, 1591-1597. https://doi. org/10.1039/jr9480001591

Champenois W, Borges AV (2019) Determination of dimethylsulfoniopropionate and dimethylsulfoxide in Posidonia oceanica leaf tissue. MethodsX 6:56-62. https://doi.org/10.1016/j.mex.2018. 12.014

Champenois W, Borges AV (2012) Seasonal and interannual variations of community metabolism rates of a Posidonia oceanica seagrass meadow. Limnol Oceanogr 57:347-361. https://doi.org/10.4319/ 10.2012.57.1.0347

Charlson RJ, Lovelock JE, Andreae MO, Warren SG (1987) Oceanic phytoplancton, atmoshperic sulphur, cloud albedo and climate. Nature 326:655-661

Colmer TD, Teresa W-MF, Läuchli A, Higashi RM (1996) Interactive effects of salinity, nitrogen and sulphur on the organic solutes in Spartina alterniflora leaf blades. J Exp Bot 47:369-375. https:// doi.org/10.1093/jxb/47.3.369

Dacey JWH, Wakeham SG, Howes BL (1987) Factors controlling emission of dimethylsulphide from salt marshes. Nature 330:643-645

Dacey JWH, King GM, Lobel PS (1994) Herbivory by reef fishes and the production of dimethylsulfide and acrylic acid. Mar Ecol Prog Ser 112:67-74. https://doi.org/10.3354/meps112067
Darmaraki S, Somot S, Sevault F, Nabat P, Cabos Narvaez WD, Cavicchia L, Djurdjevic V, Li L, Sannino G, Sein DV (2019) Future evolution of marine heatwaves in the Mediterranean sea. Clim Dyn 53:1371-1392. https://doi.org/10.1007/ s00382-019-04661-z

Dauby P, Poulicek M (1995) Methods for removing epiphytes from seagrasses: SEM observations on treated leaves. Aquat Bot 52:217-228. https://doi.org/10.1016/0304-3770(95)00500-5

de los Santos CB, Vicencio-Rammsy B, Lepoint G, Remy F, Bouma TJ, Gobert S (2016) Ontogenic variation and effect of collection procedure on leaf biomechanical properties of Mediterranean seagrass Posidonia oceanica (L.) Delile. Mar Ecol 37:750-759. https://doi.org/10.1111/maec. 12340

de Mendiburu F (2020) agricolae: statistical procedures for agricultural research. R package version 1.3-3. https://CRAN.R-project.org/ package $=$ agricolae

De Mora SJ, Lee PA, Grout A, Schall C, Heumann KG (1996) Aspects of the biogeochemistry of sulphur in glacial melt water ponds on the McMurdo Ice Shelf, Antarctica. Antarct Sci 8:15-22. https:// doi.org/10.1017/S0954102096000041

Deschaseaux E, Pontasch S, Hill R, Scott A (2018) Dimethylsulfonioproprionate (DMSP) content and antioxidant capacity in the host and endosymbionts of the sea anemone Entacmaea quadricolor are influenced by the host phenotype. J Exp Mar Bio Ecol 503:41-51. https://doi.org/10.1016/j.jembe.2017.11.006

Deschaseaux ESM, Jones GB, Deseo MA, Shepherd KM, Kiene RP, Swan HB, Harrison PL, Eyre BD (2014) Effects of environmental factors on dimethylated sulfur compounds and their potential role in the antioxidant system of the coral holobiont. Limnol Oceanogr 59:758-768. https://doi.org/10.4319/1o.2014.59.3. 0758

Dilipan E, Lucas C, Papenbrock J, Thangaradjou T (2018) Tracking the phylogeny of seagrasses: inferred from 18S rRNA gene and ancestral state reconstruction of morphological data. Proc Natl Acad Sci India Sect B Biol Sci 88:497-504. https://doi.org/10. 1007/s40011-016-0780-5

Duarte B, Martins I, Rosa R, Matos AR, Roleda MY, Reusch TBH, Engelen AH, Serrão EA, Pearson GA, Marques JC, Caçador I, Duarte CM, Jueterbock A (2018) Climate change impacts on seagrass meadows and macroalgal forests: an integrative perspective on acclimation and adaptation potential. Front Mar Sci. https:// doi.org/10.3389/fmars.2018.00190

Duarte CM (1991) Allometric scaling of seagrass form and productivity. Mar Ecol Prog Ser 77:289-300

Duarte CM, Chiscano CL (1999) Seagrass biomass and production: a reassessment. Aquat Bot 65:159-174. https://doi.org/10.1016/ S0304-3770(99)00038-8

Enríquez S, Merino M, Iglesias R (2002) Variations in the photosynthetic performance along the leaves of the tropical seagrass Thalassia testudinum. Mar Biol 140:891-900. https://doi.org/10. 1007/s00227-001-0760-y

Fox J, Weisberg S (2019) An R companion to applied regression, 3rd edn. SAGE Publications Inc, Thousand Oaks CA

Fredrickson KA, Strom SL (2009) The algal osmolyte DMSP as a microzooplankton grazing deterrent in laboratory and field studies. J Plankton Res 31:135-152. https://doi.org/10.1093/plankt/ fbn 112

Gauthier J, Wu QV, Gooley TA (2019) Cubic splines to model relationships between continuous variables and outcomes: a guide for clinicians. Bone Marrow Transpl. https://doi.org/10.1038/ s41409-019-0679-x

Giraud G (1979) Sur une méthode de mesure et de comptage des structures foliaires de Posidonia oceanica (Linnaeus) Delile. Bull Du Muséum D'histoire Nat Marseille 39:33-39

Gobert S, Kyramarios M, Lepoint G, Pergent-Martini C, Bouquegneau J (2003) Variations at different spatial scales of Posidonia 
oceanica (L.) Delile beds: effects on the physico-chemical parameters of the sediment. Oceanol Acta 26:199-207. https://doi.org/ 10.1016/S0399-1784(02)00009-9

Gobert S, Sartoretto S, Rico-Raimondino V, Andral B, Chery A, Lejeune P, Boissery P (2009) Assessment of the ecological status of Mediterranean French coastal waters as required by the water framework directive using the Posidonia oceanica rapid easy index: PREI. Mar Pollut Bull 58:1727-1733. https://doi. org/10.1016/j.marpolbul.2009.06.012

Gobert S, Lefebvre L, Boissery P, Richir J (2020) A non-destructive method to assess the status of Posidonia oceanica meadows. Ecol Indic 119:106838. https://doi.org/10.1016/j.ecolind.2020.106838

Green EP, Short FT (2003) World atlas of seagrasses. UNEP-WCMC

Haas P (1935) The liberation of methyl sulphide by seaweed. Biochem J 29:1297-1299. https://doi.org/10.1042/bj0291297

Harrell FEJ (2015) Regression modeling strategies, with applications to linear models, logistic and ordinal regression, and survival analysis, 2nd edn. Springer International Publishing

Harrell FEJ (2019) rms: regression modeling strategies. R package version 5.1-4. https://CRAN.R-project.org/package $=\mathrm{rms}$

Harrison XA, Donaldson L, Correa-Cano ME, Evans J, Fisher DN, Goodwin CED, Robinson BS, Hodgson DJ, Inger R (2018) A brief introduction to mixed effects modelling and multi-model inference in ecology. PeerJ 2018:1-32. https://doi.org/10.7717/ peerj. 4794

Hatton AD, Wilson ST (2007) Particulate dimethylsulphoxide and dimethylsulphoniopropionate in phytoplankton cultures and Scottish coastal waters. Aquat Sci 69:330-340. https://doi.org/ 10.1007/s00027-007-0891-4

Hatton AD, Darroch L, Malin G (2004) The role of dimethylsulphoxide in the marine biogeochemical cycle of dimethylsulphide. Oceanogr Mar Biol an Annu Rev 42:29-56. https://doi.org/10. 1201/9780203507810

Haworth M, Catola S, Marino G, Brunetti C, Michelozzi M, Riggi E, Avola G, Cosentino SL, Loreto F, Centritto M (2017) Moderate drought stress induces increased foliar dimethylsulphoniopropionate (DMSP) concentration and isoprene emission in two contrasting ecotypes of arundo donax. Front Plant Sci 8:1-11. https://doi.org/10.3389/fpls.2017.01016

Heck KLJ, Valentine JF (2006) Plant-herbivore interactions in seagrass meadows. J Exp Mar Bio Ecol 330:420-436. https://doi.org/10. 1016/j.jembe.2005.12.044

Hendriks IE, Olsen YS, Duarte CM (2017) Light availability and temperature, not increased $\mathrm{CO}_{2}$, will structure future meadows of Posidonia oceanica. Aquat Bot 139:32-36. https://doi.org/10. 1016/j.aquabot.2017.02.004

Husband JD, Kiene R (2007) Occurrence of dimethylsulfoxide in leaves, stems, and roots of Spartina alterniflora. Wetlands 27:224-229. https://doi.org/10.1672/0277-5212(2007)27[224: OODILS]2.0.CO;2

Husband JD, Kiene RP, Sherman TD (2012) Oxidation of dimethylsulfoniopropionate (DMSP) in response to oxidative stress in Spartina alterniflora and protection of a non-DMSP producing grass by exogenous DMSP+acrylate. Environ Exp Bot 79:44-48. https://doi.org/10.1016/j.envexpbot.2012.01.006

Jean N, Boge G, Jamet J-L, Jamet D (2006) Comparison of $\beta$-dimethylsulfoniopropionate (DMSP) levels in two mediterranean ecosystems with different trophic levels. Mar Chem 101:190-202. https://doi.org/10.1016/j.marchem.2006.03.001

Jean N, Bogé G, Jamet J-L, Jamet D, Richard S (2009) Plankton origin of particulate dimethylsulfoniopropionate in a Mediterranean oligotrophic coastal and shallow ecosystem. Estuar Coast Shelf Sci 81:470-480. https://doi.org/10.1016/j.ecss.2008.12.006

Jerković I, Marijanović Z, Roje M, Kus PM, Jokić S, Čož-Rakovac R, Kuś PM, Jokić S, Čož-Rakovac R (2018) Phytochemical study of the headspace volatile organic compounds of fresh algae and seagrass from the Adriatic Sea (single point collection), PLoS ONE 13:e0196462-e0196462. https://doi.org/10.1371/ journal.pone.0196462

Jonkers HM, Van Bergeijk SA, Van Gemerden H (2000) Microbial production and consumption of dimethyl sulfide (DMS) in a sea grass (Zostera noltii)-dominated marine intertidal sediment ecosystem (Bassin d'Arcachon, France). FEMS Microbiol Ecol 31:163-172. https://doi.org/10.1016/S0168-6496(99)00097-5

Karsten U, Wiencke C, Kirst GO (1992) Dimethylsulphoniopropionate (DMSP) accumulation in green macroalgae from polar to temperate regions: interactive effects of light versus salinity and light versus temperature. Polar Biol 12:603-607. https:// doi.org/10.1007/BF00236983

Kocsis MG, Hanson AD (2000) Biochemical evidence for two novel enzymes in the biosynthesis of 3-dimethylsulfoniopropionate in Spartina alterniflora. Plant Physiol 123:1153-1161. https:// doi.org/10.1104/pp.123.3.1153

Koenker R (2019) quantreg: quantile regression. R package version 5.52. https://CRAN.R-project.org/package=quantreg

Koenker R, Bassett GJ (1978) Regression quantiles. Econometrica 46:33-50

Koenker R, Machado JAF (1999) Quantile regression, inference processes and goodness of fit. J Am Stat Assoc 94:1296-1310

Kotak S, Larkindale J, Lee U, von Koskull-Döring P, Vierling E, Scharf KD (2007) Complexity of the heat stress response in plants. Curr Opin Plant Biol 10:310-316. https://doi.org/10. 1016/j.pbi.2007.04.011

Kuznetsova A, Brockhoff PB, Christensen RH (2017) lmerTest package: tests in linear mixed effects models. J Stat Softw 82:1-26

Larher F, Hamelin J, Stewart GR (1977) L'acide diméthylsulfonium-3 propanoïque de Spartina anglica. Phytochemistry 16:2019-2020. https://doi.org/10.1016/0031-9422(77)80117-9

Lee PA, de Mora SJ (1996) DMSP, DMS and DMSO concentrations and temporal trends in marine surface waters at Leigh, New Zealand BT. In: Kiene RP, Visscher PT, Keller MD, Kirst GO (eds) Biological and environmental chemistry of DMSP and related sulfonium compounds. Springer, US, Boston, MA, pp 391-404

Lee PA, de Mora SJ (1999) Intracellular dimethylsulfoxide (DMSO) in unicellular marine algae: speculations on its origin and possible biological role. J Phycol 35:8-18. https://doi.org/10.1046/j. 1529-8817.1999.3510008.x

Lee PA, de Mora SJ, Levasseur M (1999) A review of dimethylsulfoxide in aquatic environments. Atmos Ocean 37:439-456. https:// doi.org/10.1080/07055900.1999.9649635

Li PF, Yang GP, Liu CY (2020) Combined effects of elevated temperature and $\mathrm{pCO} 2$ on the production of DMSP and DMS in the culture of Amphidinium carterae. J Appl Phycol 32:1063-1074. https://doi.org/10.1007/s10811-020-02058-8

Liu X, He B, Guo L, Huang L, Chen D (2020) Similarities and differences in the mechanisms causing the European summer heatwaves in 2003, 2010, and 2018. Earth's Futur. https://doi.org/ 10.1029/2019EF001386

Lopez y Royo CL, Casazza G, Pergent-Martini C, Pergent G (2010) A biotic index using the seagrass Posidonia oceanica ( BiPo ), to evaluate ecological status of coastal waters. Ecol Indic 10:380 389. https://doi.org/10.1016/j.ecolind.2009.07.005

Lopez y Royo CL, Pergent G, Alcoverro T, Buia MC, Casazza G, Martínez-Crego B, Pérez M, Silvestre F, Romero J (2011) The seagrass Posidonia oceanica as indicator of coastal water quality : experimental intercalibration of classification systems. Ecol Indic 11:557-563. https://doi.org/10.1016/j.ecolind.2010.07.012

Lovelock EJ, Maggs RJ (1972) Atmospheric dimethyl sulphide and the natural sulfur cycle. Nature 237:452-453

Luy N, Gobert S, Sartoretto S, Biondo R, Bouquegneau JM, Richir J (2012) Chemical contamination along the Mediterranean French 
coast using Posidonia oceanica (L.) Delile above-ground tissues: a multiple trace element study. Ecol Indic 18:269-277. https:// doi.org/10.1016/j.ecolind.2011.11.005

Lyons DA, Scheibling RE, Van Alstyne KL, (2010) Spatial and temporal variation in DMSP content in the invasive seaweed Codium fragile ssp. fragile: effects of temperature, light and grazing. Mar Ecol Prog Ser 417:51-61. https://doi.org/10.3354/meps08818

Marín-Guirao L, Sandoval-Gil JM, Ruíz JM, Sánchez-Lizaso JL (2011a) Corrigendum to "photosynthesis, growth and survival of the Mediterranean seagrass Posidonia oceanica in response to simulated salinity increases in a laboratory mesocosm system." [Estuarine, coastal and shelf science 92 (2011) 286-296]. Estuar Coast Shelf Sci 93:86. https://doi.org/10.1016/j.ecss.2011.01.003

Marín-Guirao L, Sandoval-Gil JM, Ruíz JM, Sánchez-Lizaso JL (2011b) Photosynthesis, growth and survival of the Mediterranean seagrass Posidonia oceanica in response to simulated salinity increases in a laboratory mesocosm system. Estuar Coast Shelf Sci 92:286-296. https://doi.org/10.1016/j.ecss.2011.01.003

McFarlin CR, Alber M (2013) Foliar DMSO:DMSP ratio and metal content as indicators of stress in spartina alterniflora. Mar Ecol Prog Ser 474:1-13. https://doi.org/10.3354/meps10184

McLenon AL, DiTullio GR (2012) Effects of increased temperature on dimethylsulfoniopropionate (DMSP) concentration and methionine synthase activity in Symbiodinium microadriaticum. Biogeochemistry 110:17-29. https://doi.org/10.1007/ s10533-012-9733-0

Norie JW (1831) Section VI. The islands of Corsica and Sardinia. New piloting directions for the Mediterranean sea, the Adriatic or Gulf of Venice, the Black sea, Grecian archipelago, and the seas of Marmara and Azof. S. M'Dowall, London, pp 72-89

Otte ML, Morris JT (1994) Dimethylsulphoniopropionate (DMSP) in Spartina alterniflora Loisel. Aquat Bot 48:239-259

Otte ML, Wilson G, Morris JT, Moran BM (2004) Dimethylsulphoniopropionate (DMSP) and related compounds in higher plants. J Exp Bot 55:1919-1925. https://doi.org/10.1093/jxb/erh178

Papenbrock J (2012) Highlights in seagrasses' phylogeny, physiology, and metabolism: what makes them special? ISRN Bot. https:// doi.org/10.5402/2012/103892

Peirano A, Niccolai I, Mauro R, Bianchi CN (2001) Seasonal grazing and food preference of herbivores in a Posidonia oceanica meadow. Sci Mar 65:367-374. https://doi.org/10.3989/scimar. $2001.65 n 4367$

Prado P, Tomas F, Alcoverro T, Romero J (2007) Extensive direct measurements of Posidonia oceanica defoliation confirm the importance of herbivory in temperate seagrass meadows. Mar Ecol Prog Ser 340:63-71

R Core Team (2020) R: a language and environment for statistical computing. R foundation for statistical computing, Vienna, Austria. https://www.R-project.org/

Richir J, Abadie A, Binard M, Biondo R, Boissery P, Borges AV, Cimiterra N, Collignon A, Champenois W, Donnay A, Fréjefond C, Gobert S, Goffart A, Hecq J-H, Lepoint G, Pelaprat C, Pere A, Sirjacobs D, Thomé J-P, Volpon A, Lejeune P (2015) STARECAPMED (station of reference and research on change of local and global anthropogenic pressures on mediterranean ecosystems drifts)-Année 2014. Rapport de recherches. STARESO

Richir J, Champenois W, Engels G, Abadie A, Gobert S, Lepoint G, Silva J, Santos R, Sirjacobs D, Borges AV (2020) A 15-month survey of dimethylsulfoniopropionate and dimethylsulfoxide content in Posidonia oceanica. Front Ecol Evol 7:510

Romero J, Martínez-Crego B, Alcoverro T, Pérez M (2007) A multivariate index based on the seagrass Posidonia oceanica (POMI) to assess ecological status of coastal waters under the water framework directive (WFD). Mar Pollut Bull 55:196-204. https://doi. org/10.1016/j.marpolbul.2006.08.032
Rousseau H, Rousseau-Gueutin M, Dauvergne X, Boutte J, Simon G, Marnet N, Bouchereau A, Guiheneuf S, Bazureau JP, Morice J, Ravanel S, Cabello-Hurtado F, Ainouche A, Salmon A, Wendel JF, Ainouche ML (2017) Evolution of DMSP (dimethylsulfoniopropionate) biosynthesis pathway: origin and phylogenetic distribution in polyploid Spartina (Poaceae, Chloridoideae). Mol Phylogenet Evol 114:401-414. https://doi.org/10.1016/j.ympev. 2017.07.003

RStudio Team (2019) RStudio: integrated development for R. RStudio Inc., Boston, MA. http://www.rstudio.com/

Sandoval-Gil JM, Marín-Guirao L, Ruiz JM (2012) Tolerance of Mediterranean seagrasses (Posidonia oceanica and Cymodocea nodosa) to hypersaline stress: water relations and osmolyte concentrations. Mar Biol 159:1129-1141. https://doi.org/10.1007/ s00227-012-1892-y

Satterthwaite FE (1946) An approximate distribution of estimates of variance components. Biom Bull 2:110-114

Savva I, Bennett S, Roca G, Jordà G, Marbà N (2018) Thermal tolerance of Mediterranean marine macrophytes: vulnerability to global warming. Ecol Evol 8:12032-12043. https://doi.org/10. 1002/ece 3.4663

Silk MJ, Harrison XA, Hodgson DJ (2020) Perils and pitfalls of mixedeffects regression models in biology. PeerJ 8:1-20. https://doi. org/10.7717/peerj.9522

Simó R, Hatton AD, Malin G, Liss PS (1998) Particulate dimethyl sulphoxide in seawater: production by microplankton. Mar Ecol Prog Ser 167:291-296

Simó R, Vila-Costa M (2006) Ubiquity of algal dimethylsulfoxide in the surface ocean: geographic and temporal distribution patterns. Mar Chem 100:136-146. https://doi.org/10.1016/j.march em.2005.11.006

Speeckaert G, Borges AV, Gypens N (2019) Salinity and growth effects on dimethylsulfoniopropionate (DMSP) and dimethylsulfoxide (DMSO) cell quotas of Skeletonema costatum, Phaeocystis globosa and Heterocapsa triquetra. Estuar Coast Shelf Sci 226:106275. https://doi.org/10.1016/j.ecss.2019.106275

Spiese CE, Kieber DJ, Nomura CT, Kiene RP (2009) Reduction of dimethylsulfoxide to dimethylsulfide by marine phytoplankton. Limnol Oceanogr 54:560-570. https://doi.org/10.4319/lo.2009. 54.2 .0560

Steele L, Valentine JF (2015) Seagrass deterrence to mesograzer herbivory: evidence from mesocosm experiments and feeding preference trials. Mar Ecol Prog Ser 524:83-94. https://doi.org/10. 3354/meps 11127

Stefels J (2000) Physiological aspects of the production and conversion of DMSP in marine algae and higher plants. J Sea Res 43:183197. https://doi.org/10.1016/S1385-1101(00)00030-7

Stefels J (2009) Determination of DMS, DMSP, and DMSO in seawater. In: Wurl O (ed) Practical guidelines for the analysis of seawater. CRC Press, Boca Raton, pp 223-234

Stefels J, Steinke M, Turner S, Malin G, Belviso S (2007) Environmental constraints on the production and removal of the climatically active gas dimethylsulphide (DMS) and implications for ecosystem modelling. Biogeochemistry 83:245-275. https://doi.org/10. 1007/978-1-4020-6214-8_18

Steudler PA, Peterson BJ (1984) Contribution of gaseous sulphur from salt marshes to the global sulphur cycle. Nature 311:455-457. https://doi.org/10.1038/311455a0

Sunda W, Kieber DJ, Kiene RP, Huntsman S (2002) An antioxydant function for DMSP and DMS in marine algae. Lett Nat 418:317320. https://doi.org/10.1038/nature00851

Suzuki N, Mittler R (2006) Reactive oxygen species and temperature stresses: a delicate balance between signaling and destruction. Physiol Plant 126:45-51. https://doi.org/10.1111/j.0031-9317. 2005.00582.x 
Thume K, Gebser B, Chen L, Meyer N, Kieber DJ, Pohnert G (2018) The metabolite dimethylsulfoxonium propionate extends the marine organosulfur cycle. Nature 563:412-415. https://doi.org/ 10.1038/s41586-018-0675-0

Tomas F, Turon X, Romero J (2005) Seasonal and small-scale spatial variability of herbivory pressure on the temperate seagrass Posidonia oceanica. Mar Ecol Prog Ser 301:95-107

Valentine JF, Duffy JE (2006) Chapter 20-the central role of grazing in seagrass ecology. In: Larkum AWD, Orth RJ, Duarte CM (eds) Seagrasses: biology, ecology and conservation. Springer, pp 463-501

Valentine JF, Heck KL (1991) The role of sea urchin grazing in regulating subtropical seagrass meadows: evidence from field manipulations in the Northern Gulf of the role of sea urchin grazing in regulating subtropical seagrass meadows: evidence from field manipulations in the nort. J Exp Mar Bio Ecol 154:215-230. https://doi.org/10.1016/0022-0981(91)90165-S

Van Alstyne KL (2008) Ecological and physiological roles of dimethylsulfoniopropionate and its products in marine macroalgae. In: Amsler CD (ed) Algal chemical ecology. Springer-Verlag, Berlin, pp 173-194

Van Alstyne KL, Houser LT (2003) Dimethylsulfide release during macroinvertebrate grazing and its role as an activated chemical defense. Mar Ecol Prog Ser 250:175-181

Van Alstyne KL, Koellermeier L, Nelson TA (2007) Spatial variation in dimethylsulfoniopropionate (DMSP) production in Ulva lactuca (Chlorophyta) from the Northeast Pacific. Mar Biol 150:1127-1135. https://doi.org/10.1007/s00227-006-0448-4

Van Alstyne KL, Puglisi MP (2007) DMSP in marine macroalgae and macroinvertebrates: distribution, function, and ecological impacts. Aquat Sci 69:394-402. https://doi.org/10.1007/ s00027-007-0888-z

Vergés A, Becerro MA, Alcoverro T, Romero J (2007) Experimental evidence of chemical deterrence against multiple herbivores in the seagrass Posidonia oceanica. Mar Ecol Prog Ser 343:107114. https://doi.org/10.3354/meps06885

Walker D, Dennison W, Edgar G (1999) Chapter one. Status of Australian seagrass research and knowledge. In: Butler A, Jernakoff P (eds) Seagrass in Australia. Strategic review and development of an R\&D plan. CSIRO Publishing, Collingwood, pp 1-25

Wasserstein RL, Schirm AL, Lazar NA (2019) Moving to a world beyond "p < 0.05." Am Stat 73:1-19. https://doi.org/10.1080/ 00031305.2019 .1583913

White RH (1982) Analysis of dimethyl sulfonium compounds in marine algae. J Mar Res 40:529-536

Wickham H (2016) ggplot2: elegant graphics for data analysis. Springer-Verlag, New York

Wickham H, François R, Henry L, K. M (2019) dplyr: a grammar of data manipulation. R package version 0.8.3. https://CRAN.Rproject.org/package $=$ dplyr

Wickham H, Henry L (2019) tidyr: tidy messy data. R package version 1.0.0. https://CRAN.R-project.org/package $=$ tidyr

Zar JH (2010) Biostatistical Analysis (5th Edition). Prentice-Hall/Pearson, Upper Saddle River

Publisher's Note Springer Nature remains neutral with regard to jurisdictional claims in published maps and institutional affiliations. 